\title{
Review \\ Plants Saline Environment in Perception with Rhizosphere Bacteria Containing 1-Aminocyclopropane-1-Carboxylate Deaminase
}

\author{
Dhanashree Vijayrao Bomle ${ }^{1,+}$, Asha Kiran ${ }^{1,+}$, Jeevitha Kodihalli Kumar 1,+ , Lavanya Senapathyhalli Nagaraj ${ }^{1}$, \\ Chamanahalli Kyathegowda Pradeep ${ }^{1}$, Mohammad Azam Ansari ${ }^{2, *(\mathbb{D})}$, Saad Alghamdi ${ }^{3} \mathbb{D}$, Ahmed Kabrah $^{3} \mathbb{D}$, \\ Hamza Assaggaf ${ }^{3}$, Anas S. Dablool 4 (D), Mahadevamurthy Murali ${ }^{\text {(D) }}$, Kestur Nagaraj Amruthesh 5 , \\ Arakere Chunchegowda Udayashankar ${ }^{1, *}$ and Siddapura Ramachandrappa Niranjana ${ }^{1, *}$
}

Citation: Bomle, D.V.; Kiran, A.; Kumar, J.K.; Nagaraj, L.S.; Pradeep, C.K.; Ansari, M.A.; Alghamdi, S.; Kabrah, A.; Assaggaf, H.; Dablool, A.S.; et al. Plants Saline Environment in Perception with Rhizosphere Bacteria Containing 1-Aminocyclopropane1-Carboxylate Deaminase. Int. J. Mol. Sci. 2021, 22, 11461. https://doi.org/ $10.3390 /$ ijms222111461

Academic Editor: Marouane Baslam

Received: 24 September 2021

Accepted: 18 October 2021

Published: 24 October 2021

Publisher's Note: MDPI stays neutral with regard to jurisdictional claims in published maps and institutional affiliations.

Copyright: (c) 2021 by the authors. Licensee MDPI, Basel, Switzerland. This article is an open access article distributed under the terms and conditions of the Creative Commons Attribution (CC BY) license (https:// creativecommons.org/licenses/by/ $4.0 /)$
1 Department of Studies in Biotechnology, University of Mysore, Manasagangotri, Mysore 570006, Karnataka, India; dhanashreebomle38@gmail.com (D.V.B.); ashkiran565@gmail.com (A.K.); jeevithakk98@gmail.com (J.K.K.); lavanyaraj16@gmail.com (L.S.N.); pradeep77.gowda@gmail.com (C.K.P.)

2 Department of Epidemic Disease Research, Institutes for Research and Medical Consultations (IRMC), Imam Abdulrahman Bin Faisal University, Dammam 31441, Saudi Arabia

3 Laboratory Medicine Department, Faculty of Applied Medical Sciences, Umm Al-Qura University, Makkah P.O. Box 715, Saudi Arabia; ssalghamdi@uqu.edu.sa (S.A.); amkabrah@uqu.edu.sa (A.K.); hmsaggaf@uqu.edu.sa (H.A.)

4 Department of Public Health, Health Science College Al-Leith, Umm Al-Qura University, Makkah 21961, Saudi Arabia; asdablool@uqu.edu.sa

5 Applied Plant Pathology Laboratory, Department of Studies in Botany, University of Mysore, Manasagangotri, Mysore 570006, Karnataka, India; botany.murali@gmail.com (M.M.); dr.knamruthesh@botany.uni-mysore.ac.in (K.N.A.)

* Correspondence: maansari@iau.edu.sa (M.A.A.); acudayashankar@gmail.com (A.C.U.); niranjanasr@rediffmail.com (S.R.N.)

+ Authors contributed equally.

Abstract: Soil salinity stress has become a serious roadblock for food production worldwide since it is one of the key factors affecting agricultural productivity. Salinity and drought are predicted to cause considerable loss of crops. To deal with this difficult situation, a variety of strategies have been developed, including plant breeding, plant genetic engineering, and a wide range of agricultural practices, including the use of plant growth-promoting rhizobacteria (PGPR) and seed biopriming techniques, to improve the plants' defenses against salinity stress, resulting in higher crop yields to meet future human food demand. In the present review, we updated and discussed the negative effects of salinity stress on plant morphological parameters and physio-biochemical attributes via various mechanisms and the beneficial roles of PGPR with 1-Aminocyclopropane1-Carboxylate(ACC) deaminase activity as green bio-inoculants in reducing the impact of saline conditions. Furthermore, the applications of ACC deaminase-producing PGPR as a beneficial tool in seed biopriming techniques are updated and explored. This strategy shows promise in boosting quick seed germination, seedling vigor and plant growth uniformity. In addition, the contentious findings of the variation of antioxidants and osmolytes in ACC deaminase-producing PGPR treated plants are examined.

Keywords: salinity; ACC deaminase; rhizosphere; rhizobacteria

\section{Introduction}

The inability of plants to move from one place to another compared to other living organisms when subjected to environmental stresses can seriously impact them [1]. The environmental stresses experienced by plants are either biotic or abiotic. Biotic stresses occur when living organisms cause damage to the plants along with the deprivation of nutrients to the host, its inability to cope with such stress over time leads to plant death, 
hence resulting in pre- and postharvest loss [2,3]. Biotic stresses can occur due to bacterial, fungal and viral diseases, parasitism, physical damage by insects and nematodes, and competition and phytoparasitism by other plants [2,4]. Abiotic stresses, such as drought, water logging, salinity, extreme temperatures (cold, frost and heat), and heavy metal toxicity, are caused by non-biological components that are either environmental or nutritional, affecting the productivity of crops globally, thereby disturbing the plants' growth and development (Figure 1) [5-7]. Of arable land, 90\% is prone to these stresses resulting in yield losses of up to $70 \%$ in major food crops [8-10]. The constant exposure of plants to these abiotic stresses diminishes and limits crop yield. The stresses influence various plant responses such as changes in growth rates and crop yields, cellular metabolism and gene expression alteration, etc. Plants under stress mostly point to variations in their environmental conditions; the plant's first response in such adverse conditions occurs in the roots [3]. A healthy and biologically diverse soil that tightly holds the plant increases the plant's chances of surviving stressful conditions [11].

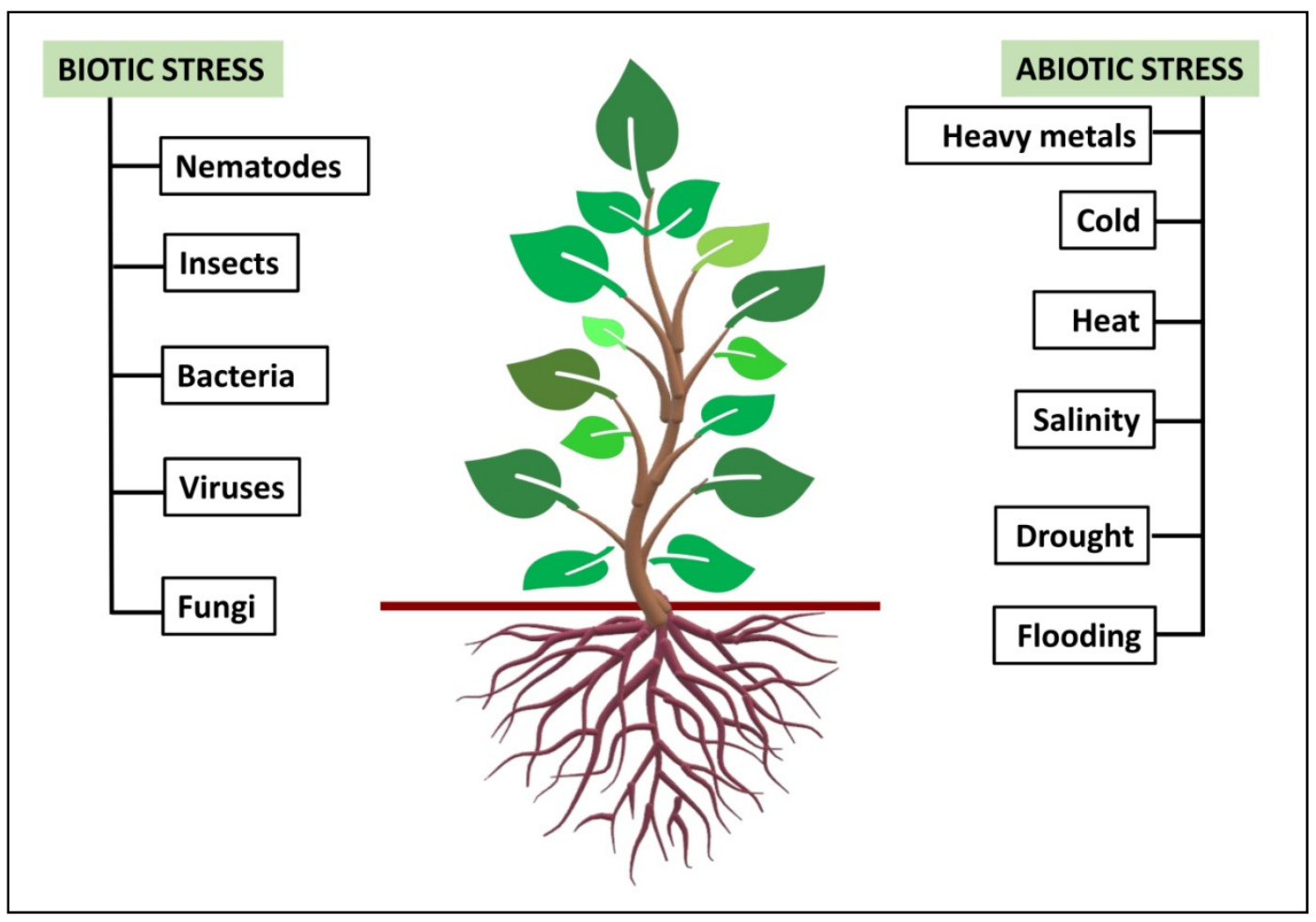

Figure 1. Different types of biotic and abiotic stresses that retard the growth and development of plants.

\section{Events in Plant Salinity Stress; Interception by Rhizobacteria Containing ACC Deaminase}

Among the abiotic stresses, salinity is considered to be one of the major environmental stresses that reduces crop yield worldwide [12]. The initial responses to salinity stress disrupt the $\mathrm{Na}^{+} / \mathrm{K}^{+}$ratio in the plant cells' cytoplasm [11]. It has been reported that in the past two decades, the degree of salinity has increased alarmingly by $37 \%$ in most irrigated land [13]. It affects the plants' physiological and metabolic processes based on the severity and duration of the stress and results in low crop yield [14]. The saline soils cause osmotic stress and ion toxicity in plants, affecting their growth [15]. When plants experience any form of environmental stress, it results in increased ethylene formation, which is harmful to the plants, as in the case of salinity.

Plant growth-promoting microorganisms are a certain class of microorganisms that aid the plant's growth either directly or indirectly. In contrast, the bacterial species aiding plant growth present at the rhizosphere are known as plant growth-promoting rhizobacteria (PGPR) [16]. The enzyme ACC deaminase produced by PGPR acts as a sink for 
1-aminocyclopropane-1-carboxylic acid (ACC, which is an immediate biosynthetic precursor of ethylene), helping to lower the plant's ethylene levels [17-20]. The metabolism of ACC by the action of this enzyme is the primary mechanism of PGPR to alleviate abiotic stresses, including salinity stress in plants [21]. The use of PGPR for aiding salinity stress tolerance is a highly beneficial green method that helps to increase plant growth and productivity [22]. Based on the importance of salinity, the present review summarizes (i) the effect of salinity stress in plants, (ii) how the plants try to withstand the salinity stress conditions, (iii) how the ethylene concentration increases during salinity stress and (iv) the mechanism of action through which PGPR alleviate salinity stress by producing ACC deaminase enzyme.

\section{Altered Responses in Plants Due to Salinity and Its Consequences}

During salinity stress, plants try to adapt to conditions by altered mechanisms at the cellular as well as the whole plant level [23]. The mechanisms at the cellular level are (i) regulation of osmotic potential, (ii) cell wall alteration, (iii) ROS elimination, (iv) vesicle transport, (v) transport protein generation, (vi) $\mathrm{K}^{+}$and $\mathrm{NO}^{3-}$ homeostasis, (vii) distribution to vacuoles, and (viii) solute production. In contrast, at the whole plant level, the tolerance mechanisms include (1) the change in flowering and fruiting times and the re-translocation of photosynthates, (2) the distribution of leaf salts to the sheath/petiole rather than to the lamina or salt allocation to epidermis cells instead of mesophyll, or its excretion [24], (3) controlling the long transport and restoration of salt in the stem, (4) change in the structure of root, (5) the excretion of more than $95 \%$ of the root salt to the soil. (6) removal of excess salts from the xylem, and (7) the development of symbiotic associations with the soil microbes such as arbuscular mycorrhizal fungi and PGPR rhizospheric bacteria.

A plant's response to salinity stress will result in the production of stress genes, which will improve plant resistance to stress. In stress, epigenetic mechanisms regulate gene expression, which include changes in DNA and RNA activity and chromatin modification $[25,26]$. Changes in membrane structures caused by salt stress create metabolic stress, produce reactive oxygen species, and impede photosynthesis, resulting in nutrient deficit $[27,28]$. Signaling chemicals including nitric oxide (NO), hydrogen sulfide $\left(\mathrm{H}_{2} \mathrm{~S}\right)$, $\mathrm{H}_{2} \mathrm{O}_{2}$, calcium, reactive oxygen species (ROS), and plant growth regulators, salicylic acid (SA), jasmonic acid (JA), ethylene (ET), and abscisic acid (ABA), all play important roles in cell signaling and crosstalk, allowing the cells to withstand a variety of stressors $[29,30]$. The adverse effects of sodium $\left(\mathrm{Na}^{+}\right)$and chloride $\left(\mathrm{Cl}^{-}\right)$ions on cellular homeostasis, as well as the osmotic potential, impacting plant physiology, particularly water intake, are the stressful consequences of salinity on plant growth [31,32]. Several homeostasis-signaling pathways are activated when plants are exposed to stresses such as salinity and drought. ROS also function as signaling products in plants, altering their stress tolerance. Plant tolerance to stress may be increased if the ROS signaling pathway response is at the appropriate level [33].

Salinity causes osmotic stress, which reduces leaf turgor by impeding water flow across the plant and reduces stomatal conductance (Gs) by closing the stomata $[34,35]$. The stomatal closure reduces the rate of transpiration (E) and the amount of $\mathrm{CO}_{2}$ available in the leaves. As a result, the intercellular $\mathrm{CO}_{2}$ concentration (Ci) decreases, causing changes in the leaf biochemistry that have a negative impact on the net $\mathrm{CO}_{2}$ assimilation rate (A) under long-term stress $[34,36]$. Salinity stress affects the various qualitative and quantitative parameters as well as major physiological processes in plants that are key factors to their existence and survival in the following ways:

\subsection{Implications on Plant Growth and Development}

When diploid Robinia pseudoacacia were treated with $250 \mathrm{mM} \mathrm{NaCl}$, wilting and chlorosis were observed in the leaves and most of them etiolated from the leaf apex, whereas growth inhibition and damage to leaves were noticed at higher concentration $(500 \mathrm{mM})$ of $\mathrm{NaCl}$ in the diploid and tetraploid R. pseudoacacia, respectively [37]. In the 
study on carnations subjected to salinity stress, the leaf area was reduced by $58 \%$ at $200 \mathrm{mM}$ $\mathrm{NaCl}$ compared to the untreated control. When carnations (Dianthus caryophyllus) were subjected to salinity stress at the flowering stage, a drastic decrease in plant height by $68 \%$ compared to the untreated plants was observed at $200 \mathrm{mM} \mathrm{NaCl}$ concentration [38]. In Koroneiki olive cultivars exposed to $100 \mathrm{mM}$ and $200 \mathrm{mM} \mathrm{NaCl}$ concentrations, the dry weight of roots was reduced by 46 and 67\%, respectively. Such negative effects were also observed in the dry weight of shoot and stem, where they declined by $91 \%$ and $77 \%$, respectively, in Koroneiki olive cultivars subjected to $200 \mathrm{mM} \mathrm{NaCl}$. Moreover, leaf dry weight was reduced by 58 and $69 \%$ at $100 \mathrm{mM}$ and $200 \mathrm{mM}$, respectively [39].

There were slightly different correlations between salinity stress and root dry weight in studies on carnations subjected to salinity stress. Though the dry weight of the root did not show any change, there was a significant decline in the stem's dry weight when the carnation was subjected to salinity stress, thus resulting in a reduced shoot/root ratio [38]. When different sorghum genotypes under salinity stress were assessed and compared to the control, i.e., non-saline condition, the genotype PAYAM showed the maximum decrease in various germination parameters except mean germination time (MGT) [40] The germination percentage (GP) and germination index (GI) decreased drastically in all sorghum genotypes subjected to salinity stress with the maximum decrease in GP and GI by 57 and $50 \%$, respectively, at $200 \mathrm{mM} \mathrm{NaCl}$ concentration. The seedling vigor index recorded a decline in the PAYAM genotype. MGT was the other seedling parameter mainly affected, which showed a significant increase in various sorghum genotypes at $100 \mathrm{mM}, 150 \mathrm{mM}$, and $200 \mathrm{mM} \mathrm{NaCl}$. The maximum MGT observed in the PAYAM genotype was $60 \%$ at $200 \mathrm{mM}$ $\mathrm{NaCl}$ compared to the control [40]. When the flowers produced by carnations subjected to salinity stress were monitored and assessed qualitatively and quantitatively, it was found that the weight and quality of the flowers decreased with increasing $\mathrm{NaCl}$ concentrations. The plants also failed to flower when grown at high concentrations (100 mM and $200 \mathrm{mM})$ of $\mathrm{NaCl}$ [38].

\subsection{Effect on Plant Biomass and Yield}

At $25{ }^{\circ} \mathrm{C}$, saline soil has an electrical conductivity (EC) value of the saturation extract (ECe) in the root zone that exceeds $4 \mathrm{dS} \mathrm{m}^{-1}$ (about $40 \mathrm{mM} \mathrm{NaCl}$ ) and an exchangeable sodium level of $15 \%$ [41]. At this value of ECe and below in several plants, the cultivation of crops leads to stunted growth, resulting in decreased crop production [42]. The phenomenon which primarily affects the plants because of the saline soil is the inhibition of seed germination, which drastically reduces the crop yield [43]. The salinity stress also leads to ionic toxicity, which disturbs the plant's osmosis and unbalances the nutrient channels [44]. The disturbance in these important processes results in altered metabolism and physiology, ultimately leading to adverse effects on seed germination and seedling growth. In addition, the salinity stress has a deleterious impact on various metrics, including shoot and root lengths, fresh and dry weights, and plant chlorophyll synthesis retardation [44].

Moreover, this stress remarkably lowers the rate of seed germination in various plants [45]. In other words, the total biomass and yield of the plant is significantly decreased due to salinity stress which acts as an indicator of the ability of plants to withstand salinity stress [46]. The calculation consists of quantification of the net assimilation rate (NAR), leaf area ratio (LAR) and relative growth rate (RGR) of the whole plant and root system [47]. The leaf area ratio (LAR) is the ratio of leaf area to leaf dry mass. Relative LAR (RLAR) is the LAR measured under salinity stress condition compared to control condition, which gives an idea of the effect of this stress on the leaf thickness. The decrease in RLAR might be adaptive in salt conditions because the leaf has thicker cell walls or a larger volume into which salts can be sequestered [48].

The total leaf area has been observed to decrease under salinity stress conditions because of altered cell wall characteristics, changed leaf turgor pressure and a reduced photosynthesis rate [49]. The research on pearl millet has shown that the studied plant's growth, productivity, and biomass were negatively impacted, particularly seed germination 
percentage, plant height, leaf area, total biomass, and crop yield [50]. The study on pea plants also revealed that salinity stress reduced its growth and yield, and ultimately its biomass. Furthermore, the studies conducted to understand the effect of salinity stress on various grain legumes indicate a reduction in crop yield in the range of $12-100 \%$ [43]. Different plant species have shown a higher dry root mass than shoot dry mass under high salinity, resulting in a higher root to shoot ratio, which is expected to improve the water and nutrient source/sink ratio under such conditions [49].

Salinity impacts flowering and fruiting patterns and reproductive physiology, which ultimately influences the agricultural yields and biomass. It has resulted in up to $50 \%$ decrease in the flowering of pigeon pea [43] and has also slowed wheat reproductive growth by limiting spike development, whereas in rice, it has reduced tillers and the formation of sterile spikelets, hence resulting in the reduction in yield [51].

\subsection{Effect on Photosynthesis in Plants}

In higher plants, photosynthesis occurs in chloroplasts, where a series of oxidation-reduction processes occur as part of light and dark reactions, converting light energy into chemical energy [52]. Light energy is used to produce ATP and NADPH and the release of oxygen during the light reaction. The ATP and NADPH produced during light reactions are used in dark reactions to fix $\mathrm{CO}_{2}$ in carbohydrates. Salinity stress affects the major physiological and metabolic processes of photosynthesis by increasing $\mathrm{Na}^{+}$and $\mathrm{Cl}^{-}$in leaf tissue of plants, which are considered stomatal, non-stomatal or both factors of photosynthetic limitation [53]. An increase in $\mathrm{NaCl}$ concentration significantly impacted stomatal closure, enzyme activity, pigment concentrations, metabolites, and the ultrastructure of various organelles such as chloroplasts, resulting in a reduced quantum yield of photosystems and a negative impact on photosynthetic efficiency $[38,39,53]$. It has also been observed that an overabundance of ROS negatively affects plant growth and production by promoting photo inhibition of PSII (photosystem II) and triggering degradation of photosynthetic pigments, oxidation of lipid molecules, and suppression of gene expression [54,55].

Sugar beet is considered a promising crop for cultivation in the saline-prone, large coastal regions in Bangladesh, as it can survive at low $(75 \mathrm{mM} \mathrm{NaCl})$ to moderate $(100 \mathrm{mM}$ $\mathrm{NaCl}$ ) salinity as assessed by (i) the abundance of relative water content, which increased the succulence of the sugar beet, (ii) elevated photosynthetic pigment, such as chlorophyll content, (iii) balanced osmolyte content, such as proline, (iv) increased the net $\mathrm{CO}_{2}$ assimilation rate, stomatal conductance, carboxylation efficiency, and water use efficiency which contributed to better carbon and mineral management and, (v) increased antioxidant enzyme, such as catalase, ascorbate peroxidase, and peroxidase activity, which detoxifies excess reactive oxygen species with $150 \mathrm{mM} \mathrm{NaCl}$ stress, gas exchange parameters, and chlorophyll content were slightly hampered [56].

\subsubsection{Effect on Chlorophyll}

Salinity induces a change in the amount of leaf chlorophyll due to impairment in the processes related to the pigment's biosynthesis and an increase in the pigment's degradation [57-59]. A drop in the concentration of precursors like glutamate and 5-amino levulinic acid in sunflower callus exposed to this stress, indicated that chlorophyll production was substantially hampered [53,60,61]. When Elaeagnus angustifolia leaves were subjected to increasing $\mathrm{NaCl}$ concentrations over a 7-day period, a drastic decrease in the contents of chlorophyll a, chlorophyll b, and the overall amount of chlorophyll was observed [62]. Transcriptome profiling indicated that seven differentially expressed genes (DEGs) were involved in the chlorophyll metabolism pathway in E. angustifolia seedlings grown under salinity stress. The DEGs encoding protochlorophyllide reductase A, protochlorophyllide reductase $C$, magnesium chelatase subunit chlD, magnesium chelatase subunit chlI, and protoporphyrinogen oxidase were downregulated after treatment with $\mathrm{NaCl}$ [62]. In research on the effect of salinity stress, the amount of chlorophyll was higher in salt-tolerant 
plant species, whereas salt-sensitive plant species had a drop in pigment content. However, the accumulation of this pigment is not always linked to salt tolerance, as various other studies have shown. For example, an experiment on tomato cultivars with varying salinity tolerance revealed a very weak relationship between the concentration of $\mathrm{Na}^{+}$and chlorophyll, implying that the ability to tolerate salinity varies with plant species [63].

\subsubsection{Effect on Stomatal Regulation, Associated Gas Exchange Properties and Enzymes} Involved in Photosynthesis

The osmotic effect induced by salinity stress causes higher abscisic acid (ABA) levels within stomatal guard cells, resulting in stomatal closure and a decrease in stomatal conductance, as well as a decrease in $\mathrm{CO}_{2}$ concentration, indicating lower photosynthesis $[38,39,53,62]$. The stomatal closure limits leaf $\mathrm{CO}_{2}$ assimilation by salinity stress which leads to the altered expression of genes encoding the key enzymes (such as Ribulose 1,5bisphosphate carboxylase/oxygenase, sucrose phosphate synthase, nitrate reductase, phosphoenolpyruvate carboxylase, and pyruvate orthophosphate dikinase) involved in the process of carbon fixation $[34,53,62]$. When the carboxylate enzyme Ribulose 1,5-bisphosphate carboxylase/oxygenase is deprived of $\mathrm{CO}_{2}$, it inhibits the carbon dioxide fixation which has been observed bothin vivoandin vitrowhen exposed to high salt concentrations [64]. This enzyme prefers $\mathrm{O}_{2}$ as a substrate instead of $\mathrm{CO}_{2}$ as it is not in adequate amounts, resulting in the generation of reactive oxygen species (ROS) such as superoxide radical $\left(\mathrm{O}_{2}{ }^{-}{ }^{-}\right)$, singlet oxygen $\left({ }^{1} \mathrm{O}_{2}\right)$, and hydrogen peroxide $\left(\mathrm{H}_{2} \mathrm{O}_{2}\right)[54,65]$. Another study found that Ribulose 1,5-bisphosphate carboxylase/oxygenase enzyme activity and protein contents were only 61 and 70\%, respectively, in E. angustifolia seedlings under salinity stress, compared to those in the control, demonstrating how it negatively affects photosynthesis [62]. The activity of enzymes involved in Ribulose 1,5-bisphosphate carboxylase/oxygenase regeneration, such as ribulose-1,5-bisphosphate (RuBP), and fructose-1,6-bisphosphatase implicated in RuBP regeneration, was found to be downregulated similarly under salinity stress $[53,62]$.

It has been noted that, increased $\mathrm{Na}^{+}$accumulation disrupts electron transport and photosystem assembly, resulting in a decrease in the ATP and NADPH produced [52,53]. The reduction in the amount of ATP produced reduces the extent of RuBP regeneration and photosynthesis rates [34]. Accordingly, various additional genes for enzymes involved in dark reactions were downregulated in E. angustifolia seedlings during photosynthesis, such as fructose-1,6-bisphosphatase which converts fructose-1,6-bisphosphate into fructose-6-phosphate as a part of Calvin cycle, triosephosphate isomerase which catalyzes the inter-conversion of dihydroxyacetone phosphate and D-glyceraldehyde-3-phosphate (isomers of triose phosphate), malate dehydrogenase which catalyzes the reversible conversion of malate into oxaloacetate, and ribose-5-phosphate isomerase which catalyzes the interconversion of D-ribose-5-phosphate and D-ribulose-5-phosphate [62]. Other enzymes that require $\mathrm{K}^{+}$as a cofactor were also significantly harmed since they were found to be affected by elevated $\mathrm{Na}^{+}$levels or the $\mathrm{Na}^{+} / \mathrm{K}^{+}$ratio [34].

With high levels of $\mathrm{NaCl}$, the amount of $\mathrm{K}^{+}$in the leaves and roots of E. angustifolia was significantly reduced, with the lowest amount of $\mathrm{K}^{+}$found in the roots, followed by expanded leaves and expanding leaves [62]. At $\mathrm{Na}^{+}$concentrations of more than $100 \mathrm{mM}$, the normal functioning of photosynthetic enzymes was found to be affected [34]. Due to the lack of carbon as a substrate, the diffusion of gases such as $\mathrm{CO}_{2}$ through stomata and leaf mesophyll decreases, lowering mesophyll conductance and impacting numerous genes $[34,53]$. As a result of this, the genes involved in photosynthesis and chloroplast folding are frequently downregulated. It is well documented that salt stress, which occurs when dehydration is combined with osmotic stress, affects a larger number of genes [34] which was substantiated in salt-sensitive sweet sorghum species, wherein the expression of genes involved in photosynthesis was downregulated [52].

\subsubsection{Effect on Photosystems}

Salinity stress affects the pigments in the photosystems involved in photosynthesis, lowering the light-absorbing efficiency of photosystems I and II, and lowering photo- 
synthetic capacity [66]. The variable/maximum fluorescence $\left(\mathrm{F}_{\mathrm{v}} / \mathrm{F}_{\mathrm{m}}\right)$ ratio depicts the maximal quantum efficiency of photosystem II, which is a measure of overall photosynthetic capability, as a linear electron transport rate [67]. In healthy leaves of most plant species, the $\mathrm{F}_{\mathrm{v}} / \mathrm{F}_{\mathrm{m}}$ ratio is normally near 0.8 ; if it is less than 0.8 , it indicates the presence of photo inhibition, a process found in stressed plants where the photosystem II centers have either been destroyed or inactivated [68]. When E. angustifolia seedlings were exposed to increasing concentrations of $\mathrm{NaCl}$, the $\mathrm{F}_{\mathrm{v}} / \mathrm{F}_{\mathrm{m}}$ ratio dropped dramatically and the expression of DEGs linked with photosynthetic-antenna proteins encoding Lhca3, Lhcb1, Lhcb3, Lhcb4, and Lhcb6 was found to be downregulated, thereby confirming that the exposure of plants to high salt concentration disrupts the formation of absorption, transfer, and distribution of light energy [62].

\subsection{Effect on Organelles}

The light and dark reactions, that makeup photosynthesis occur in the chloroplast, a salt-stressed organelle [53]. Salinity stress causes an increase in sodium and chloride ions, which irreversibly damage the thylakoid membranes, impairing electron transport and photophosphorylation. Severe damage was detected in the ultrastructure of chloroplasts exposed to salinity stress in diploid black locusts, a sensitive rice variety (Amber), and pea cultivars $[37,69,70]$. It was observed that when the plants were exposed to high salt concentrations, there was swelling in the grana and thylakoids, a reduction in the number of grana, and a noticeable shift in the form of chloroplasts from ellipsoidal to oval. Disorganized chloroplast membranes and increased plastoglobuli levels, both in terms of quantity and size, were also noticed, due to thylakoids breaking down due to salinity $[70,71]$. Apart from the chloroplast, when the leaves of a salt-sensitive plant were compared to the leaves of a salt-resistant pea plant, the former had fewer cristae and lower mitochondrial electron density [70].

\subsection{Effect on Hormone Production}

Hormones play a crucial role in plant growth and development, and they are also effective against various stress conditions, including both biotic and abiotic stress factors [72]. It is well-known that plant hormones are produced at the commencement of stress and play a critical function in maintaining plant growth and development throughout stressful situations. In response to salt stress, a variety of phytohormones such as ABA, jasmonic acid (JA), gibberellic acid $\left(\mathrm{GA}_{3}\right)$, ethylene, and salicylic acid are integrated and coordinated [73].

\subsubsection{Effect on Abscisic Acid (ABA) Production}

Abscisic acid has been found to govern seed germination and subsequent developmental activities in plants [74]. When plants are subjected to salty environments, ABA plays a critical role in reducing lateral root growth while promoting primary root growth. $\mathrm{ABA}$ is also known to play a role in several other physiological processes, including seed dormancy maintenance and delayed seed germination regulation, seed development, stomatal closure, morphologically distinct phases in embryo development, storage protein and lipid production, leaf aging, and defense against the invading phytopathogens [75]. When root cells are exposed to a saline environment, they experience osmotic stress, which causes a rise in $\mathrm{ABA}$ concentration in both root and leaf tissues within a minute [76,77]. ABA promotes the synthesis of $\mathrm{H}_{2} \mathrm{O}_{2}$ and the expression of enzyme catalase (CAT) isoform CAT1 in response to stress. In response to $\mathrm{H}_{2} \mathrm{O}_{2}$, Arabidopsis MAP2K mediates this expression [78]. One of the key signaling molecules involved in stomata closure has been discovered to be ABA [79]. During this process, ABA binds to pyrabactin resistance 1/ PYR1-like/regulatory components of ABA receptors (PYR1/PYL/RCAR). After ABA binds to its receptors, the receptors have been found to engage with PP2C phosphatases and suppress their activity, allowing SnRK2s to be released from their suppression fully [80,81], which results in activating several anion efflux channels, lowering turgor pressure and triggering stomatal closure [82,83]. 


\subsubsection{Effect on Jasmonic Acid (JA) Production}

Jasmonic acid (JA) is an endogenous growth-regulating chemical discovered in higher plants as a stress-related hormone [84]. Jasmonates (JAs) are fatty acid derivatives that include key molecules including JA, methyl jasmonate (MeJA), and jasmonate isoleucine conjugate (JA-Ile) [85]. Endogenous JA improves the tomato plant's ability to endure salinity stress, mostly through maintaining homeostasis and balance among reactive oxygen species (ROS) [86]. Meanwhile, exogenous JA also increased salinity stress resistance in two maize genotypes by increasing $\mathrm{Na}^{+}$elimination in root cells by lowering $\mathrm{Na}^{+}$influx. The JA levels were shown to rise during the early stages of salt stress, suggesting that it could be indirectly involved in the leaf growth inhibition of salt-sensitive genotypes [87]. However, other studies have shown that exogenous JA improved photosynthetic rates, proline content, ABA levels [88], and antioxidant enzyme activity [89], or lowered $\mathrm{Na}^{+}$ build-up rates in shoots, thereby reducing salt-induced injury in plants [50].

\subsubsection{Effect on Gibberellic Acid (GA) Production}

Gibberellic acid (GA) is a tetracyclic di-terpenoid molecule that stimulates plant growth and development. In addition to stimulating seed germination, GAs trigger transition from juvenile to adult leaf stage, meristem to shoot growth, vegetative to flowering, and determine sex expression and grain development [90]. Salinity decreased the endogenous bioactive GA in some plants (such as Arabidopsis seedlings), which was linked to DELLA storage. The quadruple-DELLA mutants displayed less salt-stress-induced inhibitory impact and delayed flowering, but greater salinity-mediated death, suggesting that DELLA proteins help plants survive by reducing growth in high salinity environments [91]. When seeds resume their development during seed germination, GA increases amino acid levels in the embryonic state and encourages hydrolytic enzyme production, which is necessary for the breakdown of starch present in the endosperm into monomeric units, resulting in increased plant growth and productivity [92]. In several plants, GA has been demonstrated to reduce the negative effects of salinity stress on plant development, seed germination, seed yield, yield quality, and antioxidative enzyme activity [93].

\subsubsection{Effect on Ethylene Production}

Ethylene regulates salt stress responses by activating antioxidant defense and boosting nitrate and sulphate assimilation, in addition to controlling the equilibrium of $\mathrm{Na}^{+} / \mathrm{K}^{+}$, minerals, and ROS [94]. Cao et al. [95] have reported that the usage of the ethylene precursor ACC improves tolerance to salt stress, but mutations in ethylene signaling-associated genes such as ETR1, EIN2, EIN3, and EIN4 produce hypersensitivity to increased salinity stress. The principal mechanism by which ethylene improves saltstress tolerance is by regulating and maintaining the ROS-generating and ROS-scavenging machinery [96].

\subsubsection{Effect on Salicylic acid Production}

Exogenous salicylic acid has been shown to improve the ability of plants to tolerate salinity through a variety of mechanisms. These mechanisms include better photosynthetic activity [97], increased safety against ROS and other oxidants which damage the plant cells [98], inhibition of $\mathrm{Na}^{+}$and $\mathrm{Cl}^{-}$ions accumulation in the cells under high saline conditions [99], improvement in the assimilation of elements such as $\mathrm{N}$ and $\mathrm{S}$, as these elements are essential for plant growth and development [100], the accumulation of soluble carbohydrates [101], stimulation of ABA aggregation which initiates signaling for stress tolerance [102], counteracting auxin signaling [103], and upgrading mineral nutrient uptake [104]. The ability of salicylic acid to cause the deposition of osmoprotectants, which mostly include amino acids such as proline, glycine betaine, and polyamines, is crucial for salt stress tolerance [105]. 


\subsection{Effect on Gene Expression}

Meng et al. [37] have analyzed the variations in protein expression in the chloroplasts of diploid and tetraploid R. pseudoacacia leaves under salt stress and reported that the proteins were differentially expressed and divided them into seven groups based on their function. Ribulose1,5-bisphosphate carboxylase/oxygenase activase, one of the proteins associated with the Calvin-Benson-Bassham cycle, was downregulated in tetraploid plants exposed to salinity stress. ATP synthase CF1 beta subunit, ATP synthase beta subunit, and chlorophyll a/b-binding 3C-like protein were among the proteins involved in photosynthetic electron transfer that showed a dramatic decrease in both, when exposed to salinity stress. In diploid plants, the above-mentioned ATP synthase beta subunit and chlorophyll a/b-binding 3C-like protein showed similar downregulation. Several chaperone proteins were also downregulated, including chaperone protein $\mathrm{ClpC}$, heat shock protein (putative), and chlorophyllase-2 (putative). In diploid plants exposed to $250 \mathrm{mM} \mathrm{NaCl}$, the expression of regulation/defense linked proteins such as lectin and ferritin-3 was shown to be increased. Apart from these, transketolase, enolase, glutamine synthetase, malate dehydrogenase, and proteasome subunit alpha type protein expression was also shown to be upregulated in both diploid and tetraploid plants, while upregulation was found to be greater in tetraploid plants compared to diploid plants. However, other proteins such as short chain alcohol dehydrogenase and tasselseed2-like short-chain dehydrogenase were downregulated in both diploid and tetraploid plants. Inconsistencies in gene transcription and protein expression levels were also discovered, indicating post-transcriptional regulation or post-translational processing [37].

\subsection{Biochemical and Molecular Mechanism}

Salt stress invokes a broad range of plant responses distressing its morpho-physiological, biochemical, and molecular mechanisms. The stressed plants' initial and common response is the elevation of reactive oxygen species such as peroxide $\left(\mathrm{H}_{2} \mathrm{O}_{2}\right)$ along with reactive nitrogen species such as nitric oxide (NO), which can have both positive and negative effects during stress response $[106,107]$. Undue accumulation of reactive oxygen and nitrogen species in response to stress can lead to oxidative stress damaging cellular structures [107]. The colorless gaseous molecule nitric oxide (NO) is a key compound involved in the physiology and development of plants and responses to drought, salinity and cold [106,108-110]. Nitric oxide crosstalk with other signaling chemicals and phytohormone signaling pathways has been proven to help alleviate salt stress in recent years [111,112]. Under salt conditions, sulfur and NO interact to regulate ABA and ET (ethylene) levels in the guard cell, they are also involved in the regulation of photosynthetic and stomatal activities [113]. During stress, the vital cellular functions are accomplished with a simultaneous increase of $\mathrm{H}_{2} \mathrm{O}_{2}$ and $\mathrm{NO}$ production [106,114,115]. The quinoa seed treatment with $\mathrm{CaCl}_{2}, \mathrm{H}_{2} \mathrm{O}_{2}$ and sodium nitroprusside at $0.2 \mathrm{mM}$, resulted in improved germination and germination index with significant mean germination time in both optimal and stress conditions along with a reduction in the negative effect of salt stress on $\alpha$-amylase and $\beta$-amylase resulting in starch breakdown and increased content of water soluble sugars in salt stressed seeds [116].

The reactive oxygen species $\left(\mathrm{H}_{2} \mathrm{O}_{2}\right.$ and/or hydroxyl radical) acts as a signaling molecule at a minimal amount [117]. Conversely, excess ROS has deleterious effects on growth and yield by causing the photo inhibition of photosystem II, photosynthetic pigment degradation, lipid molecule oxidation and inhibiting gene expression [54,55,118-121]. Plants scavenge the adverse ROS with efficient non-enzymatic and enzymatic antioxidant detoxification mechanisms. Tocopherols, ascorbate, phenolics, and glutathione are non-enzymatic antioxidants and superoxide dismutase (SOD), peroxidase (POX), catalase (CAT) and enzymes of the ascorbate-glutathione cycles which detoxify ROS [122-126]. The ability of plants to survive in the stressful environment depends on the signaling networks and their crosstalk [127] with activities activated after sensing of a signal by the specified receptor which triggers the influence of further signals and protein phosphorylation cascades, such as MAPK signaling [128]. The function of MAPK relies on post-translational phosphorylation signaling, established 
by a serine/threonine kinase, i.e., mitogen-activated protein kinase kinase kinase (MAPKKK or MAP3K) that reversibly phosphorylates MAPKK (a dual-specificity kinase), that then phosphorylates MAPKs [127]. At this juncture, signaling compound crosstalk, including gasotransmitters such as nitric oxide, hydrogen sulfide, hydrogen peroxide, calcium, reactive oxygen species along with growth regulators, auxin, ethylene, abscisic acid and salicylic acid has a key role in regulating stress signaling and govern unfavorable situations, such as salt stress. Recent developments in multiomics technology, transcriptomics, genomics, proteomics, and metabolomics have facilitated the highlighting of an in-depth perspective in multiple stress tolerance [129].

Plants possess a large number of genes and are acutely complex in how they react to salinity, thus it is difficult to study completely how plants react to salinity owing to their multi-genetic nature [130]. Three novel QTLs were identified on chromosomes 4, 6, and 7 associated with salt tolerance in rice through a genome-wide association study [131]. Advances such as zinc finger nuclease, transcription activator-like effector nucleases, CRISPRCas9 [132] and speed breeding [133] hold promise in developing engineered crops for salt tolerance. Genes related to stress tolerance can be isolated by analyzing the difference in transcriptional levels among tolerant and sensitive genotypes under stress. Various up and downregulated transcriptional factors such as MYB, MYB-related, AP2-EREBP, NAC, and WRKY were revealed by transcriptional profiling to study a key component in the salt tolerance network in developing salt tolerant plants [134]. In recent trend and future perspectives, it is believed that genetic resources and integrated 'omics-assisted' approaches such as phenomics, ionomics, transcriptomics, proteomics, genomics, miRNAomics, lipidomics, and metabolomics would be significantly employed for developing salt tolerance in crop species globally [135], along with epigenetics and next-generation phenotyping [136].

\subsection{Eco-Physiological Aspects and Salinity Stress}

Among many other stress factors, the key problem of worldwide soil salinization is increasing every day due to a climate change-induced rise in sea levels, intensive irrigation techniques using saline water, and large-scale soil erosion [137]. Around $20 \%$ of farmland is saline, and as a result of the major issue of global warming, even more agricultural landis becoming saline [12]. The idea of sustainable intensification of agriculture (SIA), which involves increasing agricultural output while minimizing environmental impact, is an important factor to consider in this regard $[138,139]$. Climate change impacts the intensity of various stresses, such as salinity and their resultant effects on plant growth and crop yield. Salt stress is exacerbated by three majorfactors: (i) global warming, (ii) inefficient agricultural field drainage, and (iii) increasing water table [23]. Increased air temperature shortens the growing season, leading to lower yields. As a result, the impact of climate change on yield decrease seems to be more significant in locations where temperatures are higher [140]. Low rainfall can also influence the severity of salinity due to decreased soil leaching and increased evapotranspiration, which enhancessoil salinity [141].

\section{Salt Overly Sensitive (SOS) Signaling Pathway}

Plants have developed a variety of physiological and biochemical processes to help them to thrive in high-saline environments. Because soil contains salts, the main focus of research should be on the transport mechanism of the $\mathrm{Na}^{+}$ion and its compartmentalization [142]. Ion homeostasis is defined as the transport and balancing of cytosolic ion concentration by the plasma membrane and its channel proteins, antiporters, and symporters. The $\mathrm{Na}^{+}$enters the plant passively through the root endodermis or different channels under saline conditions [12]. Plants can adjust in two ways to avoid high levels of $\mathrm{Na}^{+}$in the cytoplasm of root cells: (1) $\mathrm{Na}^{+}$exclusion from root uptake and (2) $\mathrm{Na}^{+}$ sequestration in vacuoles [73]. Exclusion, redistribution, elimination, succulence, and accumulation in the cytoplasm maintain $\mathrm{Na}^{+}$concentration in plants until their osmotic 
potential is lower than that of the soil. Holding back the excess accumulation of $\mathrm{Na}^{+} / \mathrm{K}^{+}$ and regulating the water flux are critical steps in initiating ion homeostasis [143].

Many researchers have focused their efforts on various pathways that are activated after a plant is exposed to high salt concentrations, and it has been discovered that the salt overly sensitive (SOS) stress signaling pathway is activated in order to maintain the ionic concentration and eventually achieve salt tolerance [144] and SOS1, SOS2, and SOS3 are the three key proteins in the SOS pathway (Figure 2). Many transporters maintain $\mathrm{Na}^{+}$homeostasis in root cells by preventing excess $\mathrm{Na}^{+}$ions from entering the cell cytoplasm, with the SOS1 antiporter being one of the most significant [145]. SOS1 is a plasma membrane $\mathrm{Na}^{+} / \mathrm{H}^{+}$antiporter/exchanger that removes excess $\mathrm{Na}^{+}$from root cells in the rhizosphere, which is why it is necessary to reduce ionic stress. The cytosolic C-terminal tail of the SOS1 protein is 700 amino acids long and it contains a nucleotide-binding motif as well as an auto-inhibitory domain region containing a serine residue that is phosphorylated by SOS2 [146].

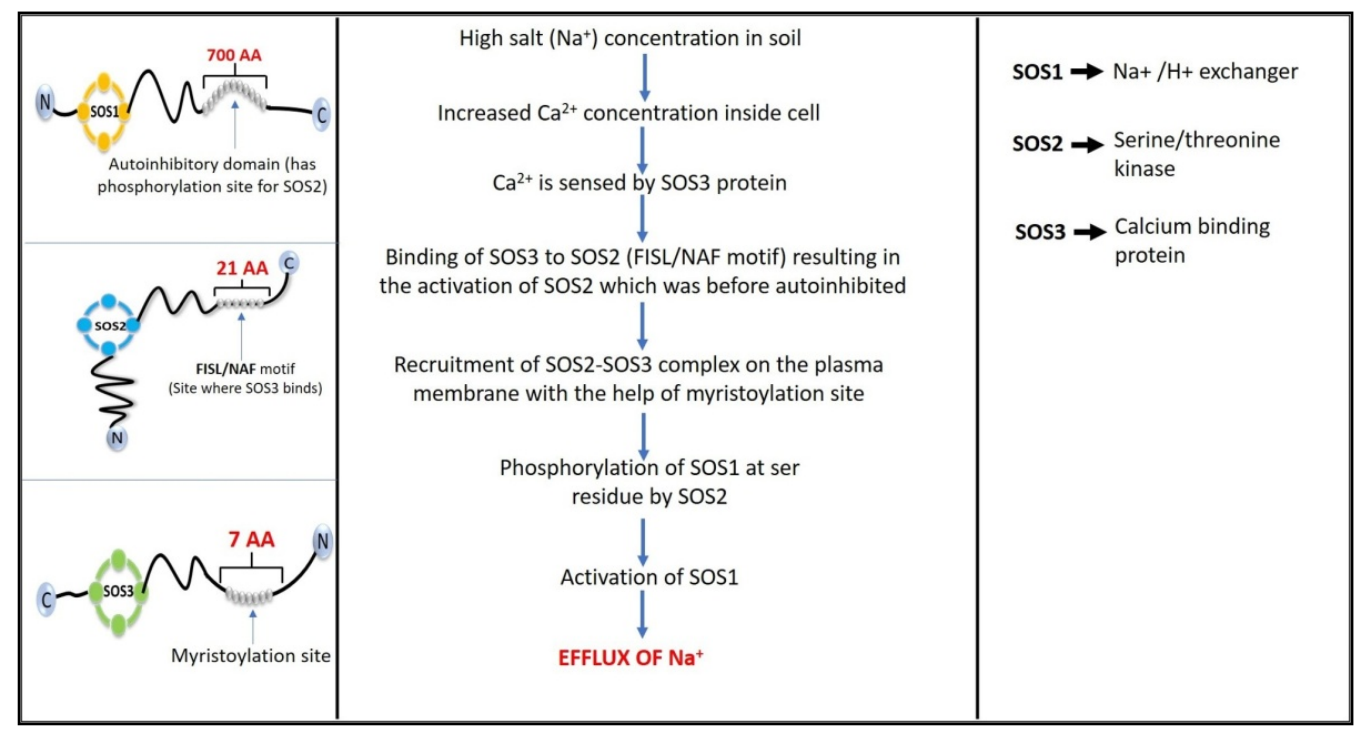

Figure 2. SOS proteins involved in SOS pathway which is primarily activated during salinity stress.

The SOS1 is auto-inhibited in normal conditions when there are no hypersaline conditions. This auto-inhibition is only relieved when the SOS2 protein adds a phosphate group to the Ser1044 residue in the C-terminal region of SOS1, which occurs when the plant is under salinity stress [146]. The SOS2 gene is responsible for producing a serine/threonine kinase enzyme [147]. The FISL/NAF motif, which comprises 21 amino acids, is found in the regulatory region of SOS2 at the C-terminus, while the catalytic domain is found at the $\mathrm{N}$-terminus, showing sequence homology with sucrose nonfermenting (SNF) kinases [148]. The interaction of the regulatory domain containing the FISL motif with the catalytic domain of SOS2 causes auto-inhibition in normal conditions. However, the calcium-dependent SOS3 protein, which interacts with SOS2 through its regulatory domain, activates SOS2 during stress [149].

Salt stress induces an increase in cytosolic $\mathrm{Ca}^{2+}$ levels, and SOS3 can detect this change in calcium level, causing SOS2 to bind to SOS3, resulting in the formation of SOS2SOS3 complex [148]. The SOS3, a Ca ${ }^{2+}$ binding protein with a myristoylation site at its $\mathrm{N}$-terminus, is the third protein in this pathway [144]. As a result of its interaction with the regulatory domain of SOS2, the SOS3 plays a key role in activating and recruiting SOS2 to the plasma membrane. On SOS3, a seven amino acid region called MGXXXS/T(K) undergoes N-myristoylation and is essential for loading the SOS3-SOS2 complex onto the plasma membrane. The SOS3-SOS2 complex activates the SOS1 via the myristoylated $\mathrm{N}$-terminus motif of SOS3 [150]. The SOS3-like $\mathrm{Ca}^{2+}$ binding protein 8 (SCaBP8) is another protein with the same function as SOS3, but with a different site of action: SCaBP8 is 
mostly active in the shoot, whereas SOS3 is primarily active in the root. After sensing altered calcium levels, both SOS3 and SCaBP8 proteins activate SOS2 via the FISL motif, which results in recruitment of the resultant complex to the plasma membrane and hence activation of SOS1. The major difference between the two proteins is that SCaBP8 lacks the seven amino acid sequence where myristoylation occurs, whereas SOS3 has it [151].

The SOS1 is responsible for transporting $\mathrm{Na}^{+}$ions from epidermal cells in roots to cells in the xylem parenchyma and ultimately to leaves, where they are sequestered in vacuoles. However, the meristematic root tip cells lack vacuoles and have SOS1 in their epidermis, which allows them to excrete $\mathrm{Na}^{+}$directly into the soil [152]. Through the action of vacuolar ATPases, SOS2 also accumulates excess $\mathrm{Na}^{+}$ions in the vacuoles. This is accomplished by binding to regulatory units that control the $\mathrm{Na}^{+} / \mathrm{H}^{+}$exchange. There are two types of antiporters in the tonoplast (plasma membrane of vacuoles). Vacuolar-type $\mathrm{H}^{+}$-ATPase (V-ATPase) and vacuolar pyrophosphatase (V-PPase) are the two enzymes involved. In Arabidopsis, the SOS stress signaling pathway has been widely researched, and the proteins involved in this process have been identified as SOS3/SCaBP8-SOS2-SOS1 signaling to regulate $\mathrm{Na}^{+}$exclusion and cellular ion homeostasis [73].

\section{Ethylene}

Ethylene is a gaseous signaling molecule that regulates stress responses as well as other developmental processes (fruit ripening, abscission of petals and leaves, senescence of flowers, stimulation of root formation, and inhibition of seedling elongation) in plants $[153,154]$ Various hormones have been found to influence plant growth, but ethylene was the first gaseous hormone found in plants to play a critical role in regulating plant growth and development under various stress conditions, including salinity stress [94,155]. Because it is gaseous, it can easily permeate into neighboring cells, even though its production takes place at the site where it must execute its hormonal function. Ethylene production induces three critical responses, collectively known as the triple response, including inhibition of hypocotyl and root extension, hypocotyl swelling, and enhanced apical hook tightness [156]. The closing of stomata influences the plant abiotic stress response, and this stomatal closure is controlled by a complicated signaling system that leads to enhanced stress tolerance [157]. Although ABA is recognized as a critical regulator of stomatal closure under abiotic stress, multiple investigations have found that ABA and ethylene have antagonistic roles in stomatal movement control $[158,159]$.

\subsection{Ethylene Biosynthesis}

There are only two processes in the production of ethylene (Figure 3). The biosynthesis of ethylene begins with the formation of S-adenosyl-L-methionine (AdoMet) from the precursor methionine, which is catalyzed by the enzyme S-adenosyl-L-methionine synthase. The rate-limiting step is the conversion of AdoMet to ACC (ethylene precursor) by the enzyme ACC synthase (ACS) [160]. The production of ethylene from ACC is an exothermic reaction in which energy is released as heat through oxygen. Because the ACS enzyme catalyzes the rate-limiting step in ethylene production, it is regulated. This enzyme is post-translationally regulated; it is first phosphorylated and subsequently destroyed by ETO1 and CUL3, which add ubiquitin molecules to the protein, which is then targeted for destruction [161].

The salt increases ethylene synthesis in various plant species by altering the activity of ACS and ACC oxidases (ACO) [162,163]. After analyzing several stress-responsive genes, it was observed that this change could be linked to epigenetic changes that affect the expression of ACS genes [164]. The Arabidopsis genome comprises 12 putative ACS-like genes; one of these ACS genes, $A C S 3$, was shown to be a pseudogene and was identified as such by a short sequence; also, $A C S 12$ and $A C S 10$ are known to code for an aminotransferase enzyme without the catalytic activity of ACS [165]. The remaining nine ACS-like genes coding for ACS proteins can be classified into three kinds based on the presence or lack of phosphorylation sites at the C-terminal [166]. 


\section{S-Adenosyl-Methionine} (AdoMet)

\section{(1) ACC Synthase}

1-aminocyclopropane-1carboxylate (ACC)

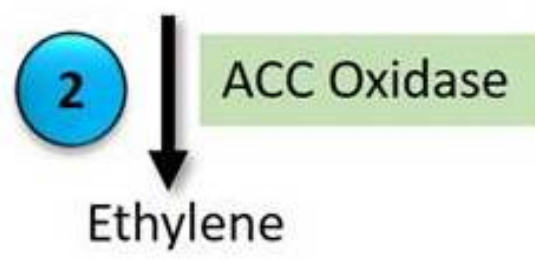

Figure 3. Steps involved in the biosynthesis of ethylene.

Type-1 ACS proteins have a long C-terminal domain with shared action sites and conserved sequences for two distinct kinases, mitogen-activated protein kinase (MAPK) and calcium-dependent protein kinase (CDPK). The TOE (target of ETO1, the ethylene overproducer 1 protein) regulatory motif overlaps the CDPK target site in the second set of proteins, type-2 ACS proteins. Type-3 ACS proteins have only a brief sequence of amino acids in their C-terminal domain and no MAPK or CDPK target sites [167]. There is a gene family known as the ethylene response factors (ERFs) among the environmental stressresponsive genes. The mRNA levels of several ERFs are known to be regulated by several compounds produced and hormones acting in diverse stress conditions [168]. Because of the stimulation and activation of $A C S$, several environmental stresses, including salinity, cause ethylene synthesis and aggregation. As a result, PIF4 regulates the transcriptional activation of ACS genes in response to abiotic stressors, including salinity and drought [169]. The transporter LHT1 absorbs the soluble ACC and distributes it throughout the plant via the xylem $[170,171]$.

\subsection{Ethylene Signaling}

Receptors detect ethylene on the membrane of the endoplasmic reticulum. It then proceeds through a signaling pathway involving signal transduction into the nucleus, resulting in changes in the expression of genes impacted by ethylene [172]. Ethylene response 1 (ETR1), ETR2, ethylene response sensor 1 (ERS1), ERS2, and ethylene insensitive 4 (EIN4) are the five ethylene receptors studied so far in Arabidopsis. These receptors negatively regulate the ethylene signaling in various plants, and they have only been found in the presence of salinity stress [172]. At their N-terminus, all receptors feature three to four membrane-spanning helices located on the plasma membrane of the endoplasmic reticulum and these helices include the ethylene binding site [173].

When ethylene isnot present, the receptors become active, and the function of these receptors can be controlled by a complex made up of two proteins: reversion to ethylene sensitivity 1 (RTE1) and auxin-regulated gene involved in organ size (ARGOS). They act as a negative regulator of ethylene sensitivity by positively regulating ethylene receptors $[174,175]$. In the absence of ethylene, active receptors have been demonstrated to bind to constitutive triple response 1 (CTR1) protein, resulting in its activation (Figure 4) [176]. A slightly higher ethylene concentration increases receptor gene transcription and stabilizes 
CTR1, whereas a higher ethylene concentration causes receptor/CTR1 to be destroyed by proteasome-mediated degradation [177]. When coupled to ethylene receptors, CTR1 is a serine-threonine kinase that remains activated. CTR1 phosphorylates and consequently deactivates EIN2, an endoplasmic reticulum membrane protein, in its active form. Two F-box proteins, such as ethylene insensitive 2 targeting protein 1 (ETP1) and ETP2, bind to this phosphorylated and deactivated EIN2, causing $26 \mathrm{~S}$ proteasomal degradation of the target protein [178]. The EIN proteins are transcription factors that bind to a certain gene and change its expression, and they also carry on the signals in the ethylene signaling pathway downstream of the CTR1 protein [179].

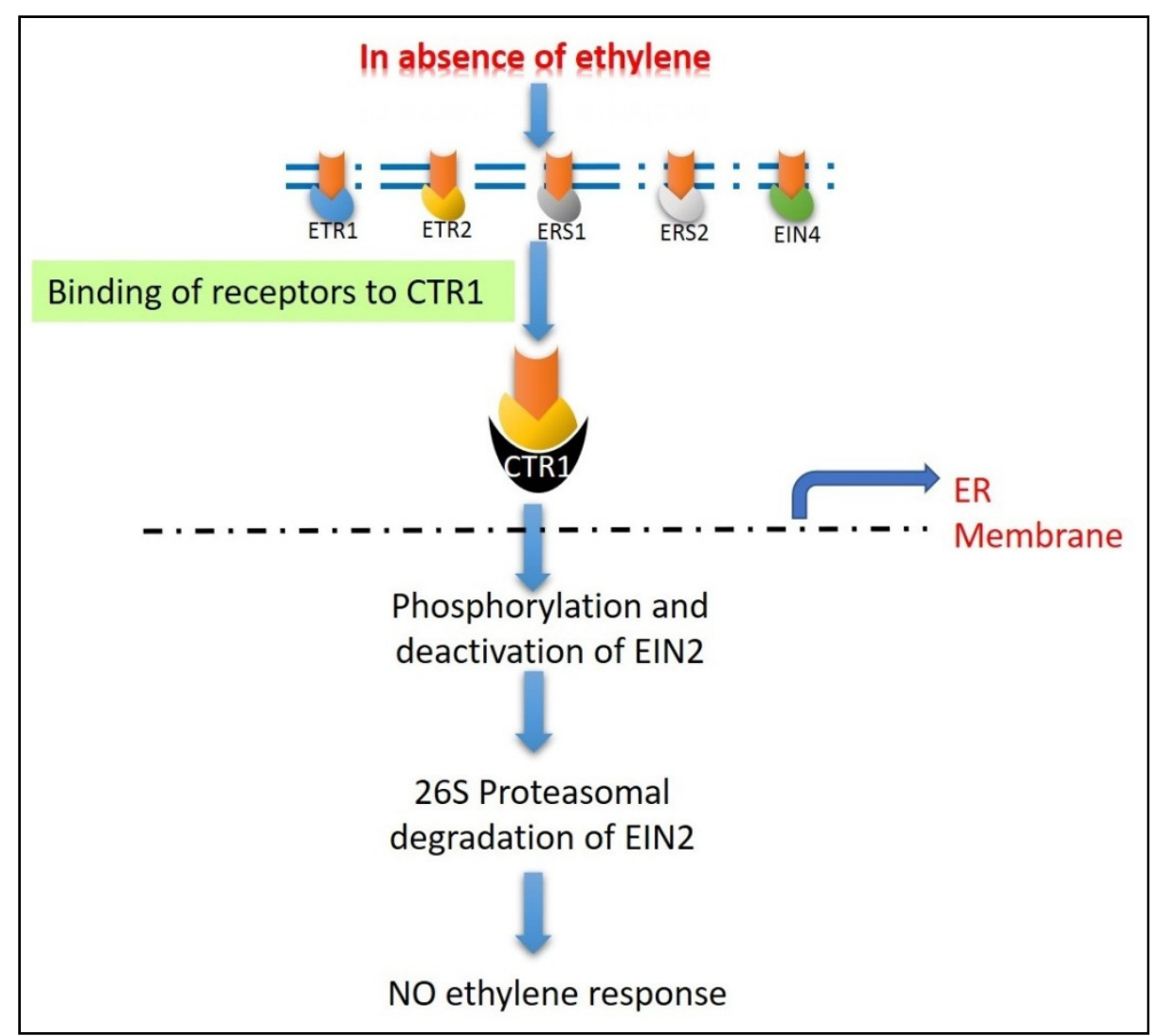

Figure 4. Signaling pathway involved in the absence of ethylene.

In addition to the five ethylene receptors, salinity stress is known to influence CTR1. Studies have shown that mutants with CTR1 loss-of-function can resist saline conditions related to manipulating the shoot $\mathrm{Na}^{+} / \mathrm{K}^{+}$ratio, which is primarily regulated by ETR1CTR1 signaling [180]. It was noted that copper $\left(\mathrm{Cu}^{2+}\right)$ ions are required for ethylene to bind to its receptors under stress conditions and this requirement for $\mathrm{Cu}^{2+}$ ions is fulfilled by a transporter called responsive to antagonist 1 (RAN1), which aids in the transfer of $\mathrm{Cu}^{2+}$ ions by ethylene. When ethylene is present in significant amounts, it binds to its receptors, causing CTR1 to be inactivated, EIN2 to be dephosphorylated, and EIN3/EILs to be activated in enhanced ethylene responses [181]. When ethylene is present, EIN3 and EIL1 boost the expression of ERFs and transcription factors (Figure 5) [182]. The salinity stress-induced stability of EIN3/EIL1 improves salinity tolerance by reducing ROS accumulation in plants [96]. 


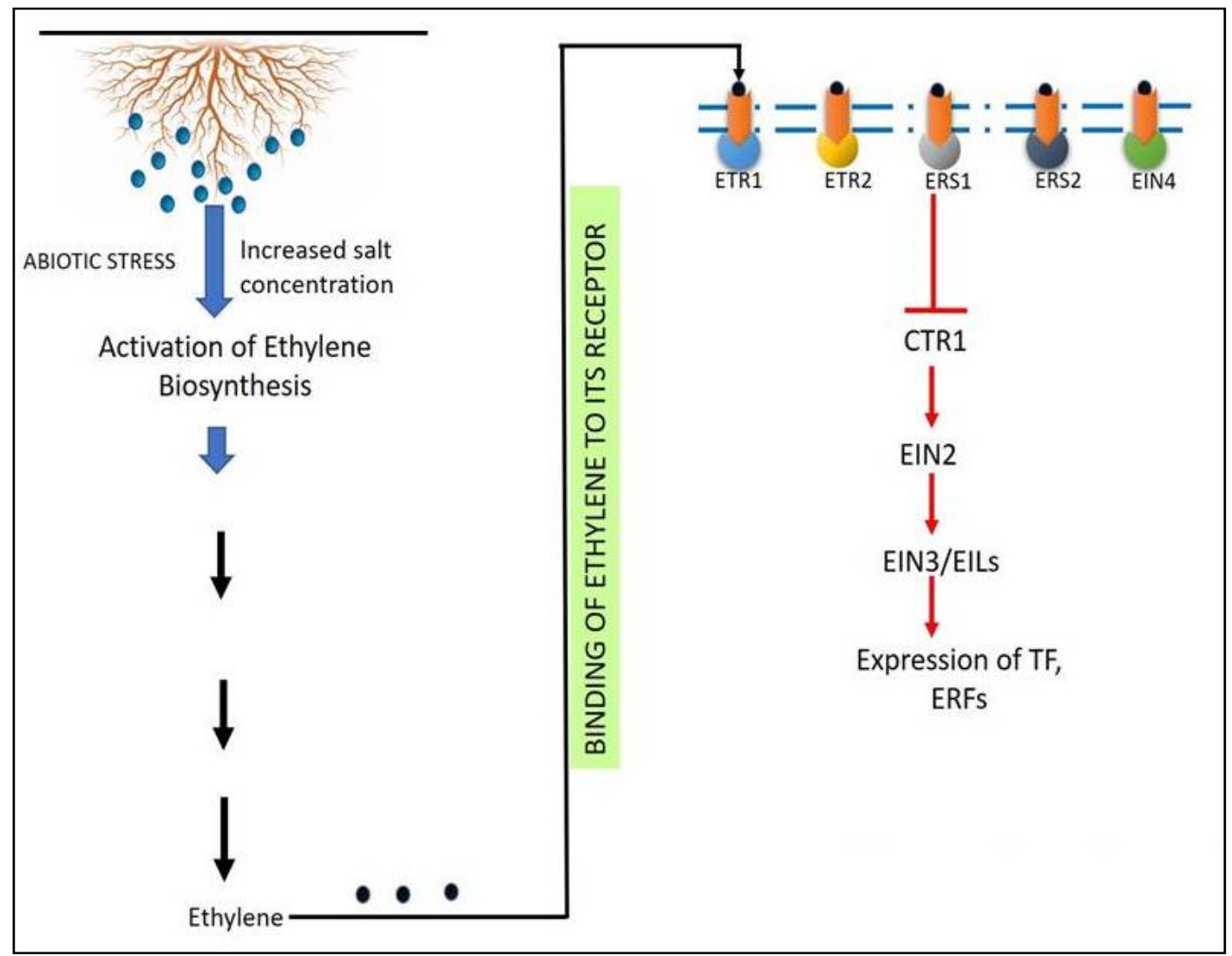

Figure 5. Ethylene signaling pathway under abiotic stress.

It is well known that high-salt soil has a detrimental impact on seed germination, which negatively impacts plant growth and net yield [12]. Different components and factors of ethylene signaling have a beneficial or detrimental impact on the seed germination process and subsequent growth in a saline environment [183]. Seed germination was found to be negatively influenced by ETR1 and EIN4 in Arabidopsis plants. However, ETR2 favorably regulated the process and was found to enhance seed germination under salinity stress [184]. Elongated hypocotyl 5 (HY5) protein upregulates $A B A$ insensitive 5 (ABI5) gene expression and this increase of $A B I 5$ is responsible for limiting and preventing seed germination. EIN3/EIL degrades the HY5 protein, allowing constitutive photomorphogenesis 1 (COP1) to reach the nucleus [185]. During salinity stress, after HY5 is broken down, ABI5 expression is halted, and seed germination inhibition is consequently stopped [94].

Ethylene-responsive element binding factors (ERFs) are transcription factors that play a role in the ethylene signaling cascade downstream of EIN3 [94]. ERF1, ERF2, ERF5, $E R F 6, E R F 8, E R F 9, E R F 11, E R F 59, E R F 98$, and RAP2.6L have been shown to play a role in the transcriptional cascade that governs the suppression of leaf growth when exposed to mild osmotic stress [186]. The majority of ERFs are positively influenced by activating the response, and their concentration rises quickly after exposure to stress, although two ERFs, $E R F 8$ and ERF9, are negatively influenced. After some time, these two ERFs are engaged to reduce the risk of over activation and allow the fine-tuning of the stress response. This signaling is transcriptionally activated in response to osmotic stress, but it has also been reported to work in response to abiotic stress factors such as salinity and drought stress. ERF8 has a substantial inhibitory effect on leaf cell proliferation and growth [187]. It has been observed that after being phosphorylated via the MPK3/6-cascade to regulate ethylene production, the activity of some ERFs increases, resulting in dual level response regulation mediated by ERFs [188]. 


\section{Role of ACC Deaminase to Overcome the Salinity Stress}

The presence of ACC deaminase, encoded by the acdS gene and having 325-345 amino acid residues, has been found in all three domains of life: archaea, bacteria, and eukarya. It is a multimeric enzyme of monomeric subunits with a molecular weight of $33-42 \mathrm{kDa}$ that can function as a homodimer, homotrimer, or homotetramer $[189,190]$.

\subsection{Structure}

X-ray crystallographic analysis revealed that ACC deaminase folds into two domains, each with an open twisted $\alpha / \beta$ structure similar to the $\beta$-subunit of tryptophan synthase [191]. When structural analysis using nuclear magnetic resonance, $X$-ray crystallography [192] and mutagenesis was carried out in yeast [193] and Pseudomonas [194,195], the residues mainly constituted the enzyme's active site viz., Tyr269, Tyr295, Lys51 and Glu296 (yeast ACC deaminase numbering sequence), while similar residues viz., Tyr268, Tyr294, Lys51 and Glu295 were found in Pseudomonas sp. UW4. The amino acid residues that make up the enzyme's active site have important functions. For example, Lys51 is involved in ACC proton extraction, while Tyr294 is a catalytic residue that helps position Pyridoxal 5'-phosphate (PLP) cofactor correctly within the active site and aids in external aldimine formation by interacting with the amino group of the substrate [192,194].

\subsection{Enzyme Biochemistry and Its Function}

ACC deaminase is a pyridoxal 5-phosphate-dependent tryptophan synthase beta super family (fold type II) hydrolase that is involved in the breakdown of ACC, an immediate precursor associated with ethylene synthesis via the methionine pathway, by employing the cofactor pyridoxal phosphate [190,192]. Because the enzyme's activity relies on its substrate, ACC, the enzyme is inducible. ACC deaminase activity can be induced by ACC at levels as low as $100 \mathrm{nM}$ in Pseudomonas sp. with complete induction up to $10 \mathrm{~h}$ [196]. The enzyme degrades ACC by opening the cyclopropane ring and deaminating it, resulting in the production of $\alpha$-ketobutyrate and ammonia [17,197-199]. As a result, when plants are inoculated with PGPR, which produces this ACC deaminase, the inhibitory ethylene levels in plants under stress are reduced.

\subsection{Mechanism of Action of the Enzyme on Its Substrate ACC}

Two reaction mechanisms have been proposed: direct $\beta$-hydrogen abstraction is the first mechanism and indirect $\beta$-hydrogen abstraction by nucleophilic addition is the second mechanism. Internal aldimine is formed when the Lys residue of the ACC deaminase enzyme combines with the PLP cofactor in both cases. Transaldimination occurs next, in which internal aldimine is acted on by ACC and transformed to external aldimine via an aminyl intermediate. Both reaction mechanisms differ in terms of the reactions that lead to quinoid formation, which can be either direct or indirect $\beta$-hydrogen abstraction, resulting in the formation of products such as aminocrotonate and quinoid, which reversibly hydrolyzes to generate $\alpha$-ketobutyrate and ammonium, culminating in internal aldimine regeneration $[197,200]$.

The methylene proton undergoes direct $\beta$-hydrogen abstraction via the Lys51 residue of ACC deaminase, forming a quinonoid, where electronic rearrangements and protonation occur, forming another quinonoid, which is nucleophilically attacked by the protein's basic residue. However, during indirect $\beta$-hydrogen abstraction, the formation of external aldimine is followed by a nucleophilic attack through a basic residue of the pro-S $\beta$-carbon of ACC, as well as the removal of a proton from another nearby basic residue, resulting in ring opening and the formation of a quinoid $[197,200]$. Because of its electrical structure and thermodynamic favorability, the indirect mechanism is more favorable as a primary reaction used by ACC deaminase. To elucidate this, a mutant enzyme was utilized to isolate the reaction intermediates because the direct mechanism does not adequately account for the mechanism of action of the enzyme in its original form. Furthermore, the reaction is 
predicated on an inert proton abstraction followed by anion-induced cleavage, which is stereoelectronically unfavorable [200].

\subsection{Transcriptional Regulation of ACC Deaminase Gene (acdS)}

The expression of the ACC deaminase gene (acdS) is influenced by the type of organism and the surrounding environment. At least one of these factors, namely (i) leucineresponsive regulatory protein (LRP) coupled with cyclic AMP receptor protein (CRP) and fumarate-nitrate reduction regulatory protein (FNR), (ii) nitrogen fixation (nifA) genes, (iii) RNA polymerase sigma $S$ (rpoS) gene and (iv) other modes of enzyme regulation, regulates the transcription of these acdS genes [190]. Other factors, including oxygen availability, substrate concentration, and product concentration affect the expression of this enzyme in addition to these transcriptional factors. Various investigations have shown that different phylogenetic groupings use different mechanisms to regulate this gene's expression, implying that these modes of regulation are quite complex [190,191].

There are several ways for transcriptional regulation and expression of the acdS gene in bacteria, as explained below.

\subsubsection{LRP Coupled with CRP and FNR}

The acdS gene is regulated by several transcription factors working together. The CRP box, FNR box, $a c d B$ gene, $a c d R$ binding site, and $a c d R$ gene expressing open reading frame (ORF) were among the regulatory elements discovered in an extensively investigated Pseudomonas sp. UW4 strain [201-204]. The $a c d R$ gene (ACC deaminase regulatory gene encoding LRP protein) transcription and expression are promoted in the presence of ACC, resulting in the synthesis of LRP [190]. In its active state, LRP binds to a complex formed by ACC and glycerophosphoryl diester phosphodiesterase, both expressed by the $a c d B$ gene, to form a tripartite regulatory complex $[190,204]$. This tripartite regulatory complex then binds to either FNR box (if $\mathrm{O}_{2}$ levels are low) or $\mathrm{CRP}$ box (if $\mathrm{O}_{2}$ levels are high) and activates the acdS promoter region (P2 or P3), causing the initiation of acdS gene expression [190].

In bacteria that lack CRP or FNR box, the regulatory complex binds ACC directly to the acdS promoter [205]. As a result, ACC deaminase is produced, breaking down the substrate ACC into ammonia and $\alpha$-ketobutyrate, forming branched-chain amino acids such as leucine. When the concentration of leucine rises, it attaches to the active LRP octamer, transforming it into an inactive dimer-leucine complex, which helps suppress the expression of the $a c d S$ gene. The $a c d S$ gene is regulated so that it only transcribes when needed (Figure 6) [204].

\subsubsection{Nitrogen Fixation (nifA) Genes}

When the bacterial strains produce the ACC deaminase enzyme but the DNA sequence does not encode for an $a c d R$ gene, the transcription of the acdS gene is controlled by the nifA promoter, which is associated with transcriptional regulation of nitrogen fixation (nif) genes, as in the case of a few strains of Rhizobia and Mesorhizobium (Figure 7) $[190,206]$. The components present are the regulatory $\mathrm{N}_{2}$ fixing units, namely nif $A 1$ and nif $A 2$, which are present upstream of acdS and nifH in Mesorhizobium loti. The nifA2 promoter, which codes for the nifA2 protein, interacts with the $\sigma 54$ RNA polymerase, permitting acdS transcription [197]. The nifA1 gene has also been identified to regulate acdS gene expression; however, its exact role is unknown [206]. This mechanism aids nodules containing such bacterial strains in controlling high ethylene levels, preventing senescence in the plant at an early stage [190]. 


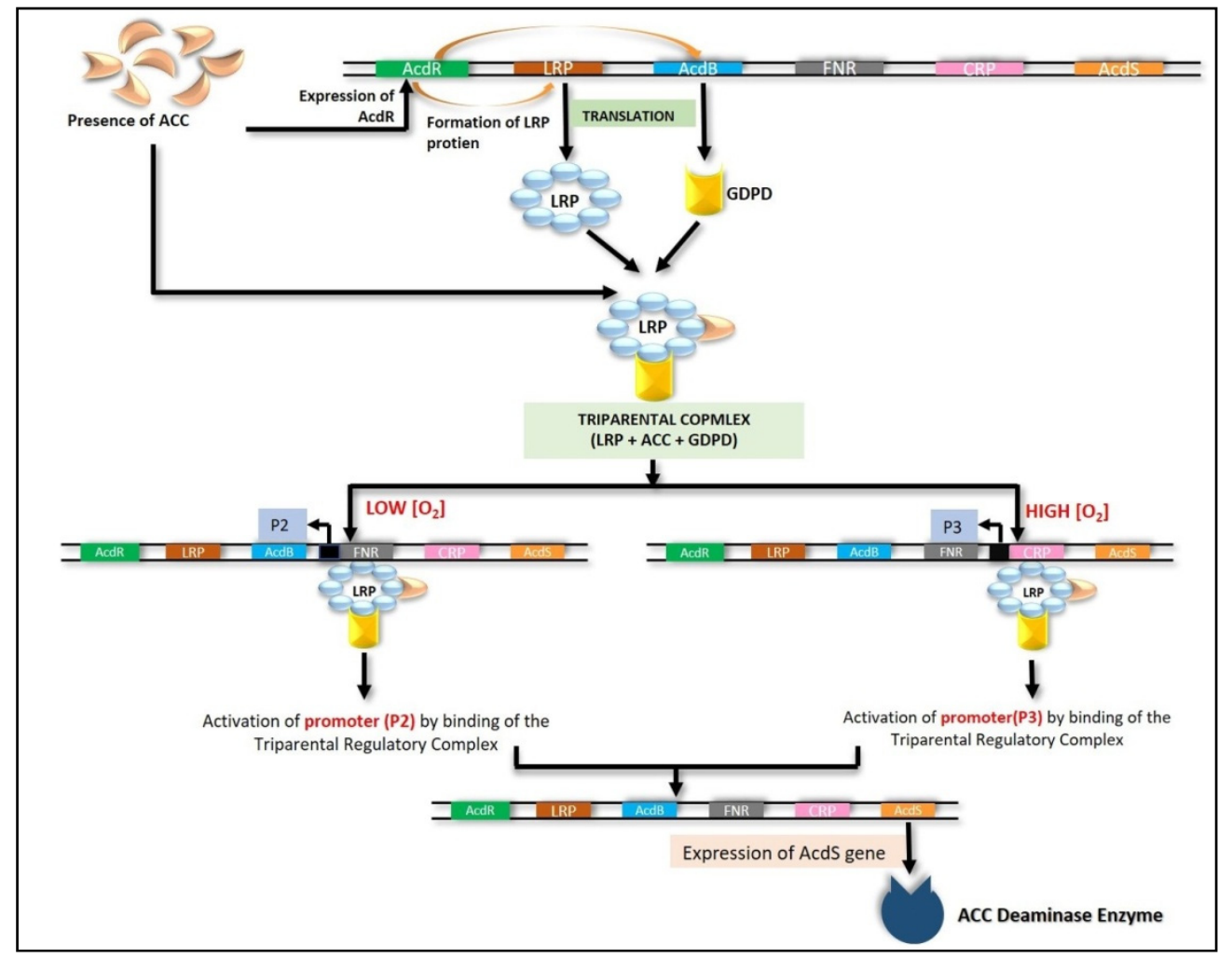

Figure 6. Transcriptional regulation of acdS gene by the action of octameric LRP protein.

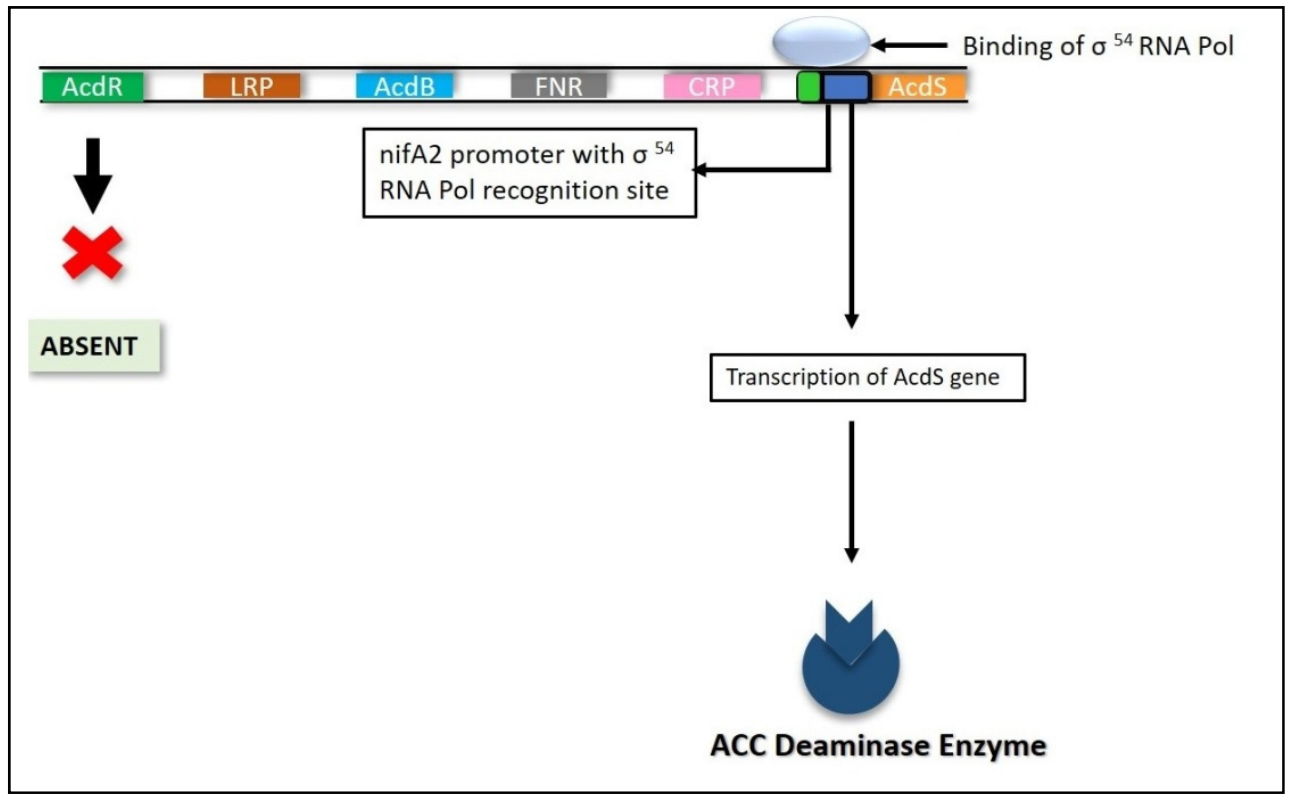

Figure 7. Regulation of acdS gene by nifA2 promoter.

\subsubsection{RNA Polymerase Sigma S (rpoS) Gene}

The expression of many genes produced when bacteria are in the stationary phase of their growth or response to various stress stimuli is largely regulated by the sigma factor rpoS, an important stress modulator in $\beta$ and $\gamma$ Proteobacteria [207-209]. In a study to better understand the relationship between $r p o S$ and $a c d S$ gene expression, researchers found that over-expression of the rpoS gene resulted in a 30\% increase in ACC deaminase levels in a genetically modified ACC deaminase-positive strain of Enterobacter cloacae CAL2 with numerous rpoS gene copies on a plasmid [207]. The contrasting result was also 
observed when the same experiment was performed on Pseudomonas sp. UW4, the levels of ACC deaminase were found to be $20 \%$ lower when compared to the untransformed wild type [207]. Although the genes are $96 \%$ similar, the acdS gene and rpoS gene have a positive and negative correlation in both cases, demonstrating how separate transcriptional regulators control the process $[210,211]$.

\subsubsection{Other Modes of Regulation}

Despite the complete absence or partial expression of the $a c d R$ gene, some ACC deaminase-positive bacteria produce the enzyme [190]. Even though they are almost $9 \mathrm{~kb}$ away from the $a c d S$ gene, $a c d R$ or a similar gene that produces LRP that can influence the expression of acdS gene [191]. Different species of bacteria, even though they belong to the same genus, Burkholderia, differ in terms of transcriptional regulation, with the two strains Burkholderia sp. CCGE1002 and Burkholderia phymatum STM815 lacking the acdR gene but having two acdS gene copies, one on the bacterial chromosome and the other on the mega plasmid [197]. In B. xenovorans LB4000, another species in the same genus, the transcription of acdS is controlled by the LysR family of regulatory elements, which is a fundamentally distinct mechanism of regulation [141]. In addition, Brenneria sp. EniD312, Dickeya sp., and Pantoea sp. At-9B is an example of Acinetobacter sp. and Proteobacteria sp. that use the LysR family of regulatory elements to control the transcription of this gene [191]. The acdS gene is regulated by a gene related to the regulatory protein GntR in other Actinobacteria and Meiothermus species. Other mechanisms involving operon regulatory factors like M20 peptidase may have regulated this gene in Saccharopolyspora erythraea NRRL 233 and Streptomyces hygroscopicus ATCC 53653 acdS is part of the major facilitator super family (MFS) proteins, which are also controlled by the same operon regulatory factors [191].

\section{Plant Growth-Promoting Rhizobacteria (PGPR)}

At each stage of its growth and development, a plant might be harmed by biotic and abiotic stressors. Though biotic stresses can be avoided or treated with chemical components, abiotic stresses are inescapable and difficult to manage, resulting in a loss of more than $50 \%$ for most crop plants [212,213]. PGPR has been a particularly effective approach for reducing the bad effects generated by both types of stress factors, among the various methods designed to deal with such situations. The PGPR is a type of bacteria that lives in the rhizosphere, a specialized area around the roots of a range of leguminous and non-leguminous plants, and performs many biological and ecological functions [214]. The rhizosphere is a tiny soil zone surrounding the root system with a higher concentration of important and helpful nutrients than the rest. This is due to a large number of disseminated plant components such as amino acids and sugars. These disseminated components are high in nutrients and energy, which have a beneficial impact on various microbes' growth and metabolic activities, resulting in the region being heavily flooded with bacteria [215].

The plant-to-microbe signal molecule, genistein, has been used for the alleviation of salt stress during $(\mathrm{N})$-fixation in soybean by a species of legume-root nodulating, micro symbiotic nitrogen-fixing bacteria Bradyrhizobium japonicum by inducing particular bacterial genes allowing the bacteria to progress through the $\mathrm{N}$-fixation process and fix atmospheric nitrogen while being environmentally and economically viable [216-218] along with other soil microbes including plant growth-promoting rhizobacteria and mycorrhizal fungi under both greenhouse and field conditions $[219,220]$. In wheat, it has been observed that resistant species use a range of mechanisms to mitigate salt stress, including sodium exclusion, osmoregulation and potassium retention. The most crucial are biotechnology-based crop breeding, seed priming and soil microbes, using resistant genotypes or combining these methods, and the scientific use of irrigation water [140].

The PGPR is divided into extracellular PGPR (ePGPR) and intracellular PGPR (iPGPR). The ePGPR (such as Serratia, Azospirillum, Azotobacter, Bacillus, Chromobacterium, Caulobacter, Agrobacterium, Erwinia, Pseudomonas, etc.) reside and function outside of plant root cells, in soil intimately linked with roots (rhizosphere), on root surfaces (rhizoplane), and in spaces 
between root cortex cells. The endophytes/symbionts of the iPGPR (such as Rhizobium, Bradyrhizobium, Allorhizobium, Mesorhizobium, etc.) as endophytes/symbionts live inside the plant root cells. These PGPR are known to synthesize extracellular hydrolytic enzymes such as chitinases, glucanases, cellulases, and proteases that cause cell lysis and the destruction of fungal cell walls, one of which is ACC deaminase [214]. This unique group of rhizobacteria is also known to produce biosurfactants, which can negatively act on pathogenic microbes by disrupting the permeability of their plasma membrane, resulting in cell lysis. They also produce siderophores, which can slow the growth of pathogenic organisms by reducing iron availability [214,221].

Under high salt conditions, the enzyme ACC deaminase has been shown to play a critical role in nodule formation, promoting the persistence of infectious conditions that would otherwise be harmed by extremely raised amounts of ethylene, which aids in nodule formation [222]. Many PGPR live on the surface of roots and thrive in the areas between the root hairs and the rhizosphere's epidermal layers. However, it has also been discovered that some PGPR species do not physically contact the roots. Chemicals secreted from roots, also known as root exudates, are the most significant aspect of rhizospheric signaling and control beneficial interactions between plants and microbes. Many secondary metabolites released by plant root cells, such as phenolic compounds, flavonoids, and other organic acids, act as chemical messengers, causing bacterial cells to migrate towards these secondary metabolites, a process known as bacterial chemotaxis. They also help with exopolysaccharide secretion, quorum sensing (bacterial cell signaling), and biofilm development during rhizosphere invasion [223].

Plant hormones, exopolysaccharides, rhizobitoxine, and lipochito-oligosaccharides are all known to be produced by PGPR [224,225]. Rhizobitoxine inhibits the production of ethylene in plants, allowing them to develop more quickly under stress. Pseudomonas, Bacillus, Enterobacter, Agrobacterium, Streptomyces, Klebsiella, and Ochromobacter are the best-known PGPR for increasing agricultural yield in saline environments [226]. The potential of halotolerant plant growth-promoting rhizobacteria (HT-PGPR) to endure and reduce salinity stress in plants is well established. Several HT-PGPR species, including Arhrobacter, Azospirillum, Alcaligenes, Bacillus, Burkholderia, Enterobacter, Microbacterium, Klebsiella, Pseudomonas, Streptomyces, Rhizobium, and Pantoea, have been observed to help crops cope with salinity stress [227]. After being inoculated with a salt-tolerant PGPR (ST-PGPR) strain of Enterobacter sp. UPMR18 that can synthesize ACC deaminase, the authors of [228] found that increased production of ROS as well as scavenging enzymes such as superoxide dismutase (SOD), ascorbate peroxidase (APX), and catalase (CAT) and the upregulation of ROS signaling genes led to improved crop production. The activation of the ACC deaminase gene in ST-PGPR after exposure to high saline conditions is a common phenomenon, and as a result, the ethylene concentration, which rises due to salinity stress, is reduced by ST-PGPR. This is accomplished by inhibiting the ethyleneinduced downregulation of genes associated with plant stress and the upregulation of genes associated with plant growth [229].

\section{Role of ACC Deaminase Producing PGPR in Alleviating Salinity Stress}

Ethylene is the main hormone produced when plants respond to salinity stress. When the amount of stress ethylene produced exceeds a particular threshold, it has a negative impact on plant growth. The PGPR employs various techniques to alleviate plant stress, one of which is using an enzyme called ACC deaminase, which helps lower ethylene levels. The PGPR with more than $20 \mathrm{nmol}$ of $\alpha$-ketobutyrate $\mathrm{mg}^{-1} \mathrm{~h}^{-1}$ of ACC deaminase activity promotes plant growth by significantly reducing stress ethylene in stressed plants [230]. The mechanism of action of this enzyme is to degrade ACC to $\alpha$-ketobutyrate and ammonia, which are then utilized as a source of nitrogen and carbon by bacteria, allowing the plant to resume development by lowering stress ethylene levels [196,231]. Further, the application of PGPR possessing the ACC deaminase activity in inducing salt tolerance is listed in Table 1 and their beneficial role in plant growth is depicted in Figure 8. 
Table 1. PGPR mediated induction of salinity stress in plants.

\begin{tabular}{|c|c|c|c|c|c|}
\hline Bacteria Used & Plant & $\begin{array}{c}\text { Salt } \\
\text { Treatment }\end{array}$ & $\begin{array}{l}\text { Mode of } \\
\text { Treatment }\end{array}$ & Beneficial Effects & References \\
\hline $\begin{array}{l}\text { Staphylococcus } \\
\text { kloosii, Kocuria } \\
\text { erythromyxa }\end{array}$ & Raphanus sativus & $80 \mathrm{mM}$ & Seed & $\begin{array}{l}\text { Increased fresh and dry } \\
\text { root weight, fresh and dry } \\
\text { shoot weight, chlorophyll } \\
\text { content, plant nutrient } \\
\text { element contents of leaves }\end{array}$ & Yildirim et al. [232] \\
\hline $\begin{array}{l}\text { Pseudomonas } \\
\text { fluorescens }\end{array}$ & Zea mays & $15 \mathrm{dS} \mathrm{m}^{-1}$ & Seed & $\begin{array}{l}\text { Increased root length, } \\
\text { plant height, phosphorous } \\
\text { uptake, nitrogen uptake } \\
\text { with enhanced grain yield }\end{array}$ & Nadeem et al. [233] \\
\hline Pseudomonas putida & $\begin{array}{l}\text { Gossypium } \\
\text { hirsutum }\end{array}$ & $\begin{array}{l}\text { Secondary } \\
\text { salinized } \\
\text { soil type }\end{array}$ & Seed & $\begin{array}{l}\text { Increased germination } \\
\text { rate, fresh and dry weight, } \\
\text { plant height, } \mathrm{K}^{+} \\
\text {concentration }\end{array}$ & Yao et al. [234] \\
\hline $\begin{array}{l}\text { Enterobacter } \\
\text { aerogens, } \\
\text { Bacillus brevis }\end{array}$ & $\begin{array}{l}\text { Solanum } \\
\text { melongena }\end{array}$ & $25 \mathrm{mM}$ & Seedling & $\begin{array}{c}\text { Increased shoot fresh and } \\
\text { dry weight, root dry } \\
\text { weight, uptake of N, P } \\
\text { and K }\end{array}$ & $\begin{array}{c}\text { Abd El- } \\
\text { Azeem et al. [235] }\end{array}$ \\
\hline $\begin{array}{l}\text { Bacillus subtilis, } \\
\text { Pseudomonas } \\
\text { fluorescens }\end{array}$ & Raphanus sativus & $\begin{array}{l}75 \mathrm{mM} \text { and } \\
150 \mathrm{mM}\end{array}$ & Seed & $\begin{array}{l}\text { Increase fresh and dry root } \\
\text { mass, fresh and dry shoot } \\
\text { mass, fresh and dry leaf } \\
\text { mass, chlorophyll content, } \\
\text { carotenoid content, total } \\
\text { photosynthetic pigment } \\
\text { contents with improved N } \\
\text { and P nutrition in plants }\end{array}$ & $\begin{array}{c}\text { Mohamed and } \\
\text { Gomaa [236] }\end{array}$ \\
\hline $\begin{array}{l}\text { Bacillus aryabhattai, } \\
\text { Brevibacterium } \\
\text { epidermis, } \\
\text { Micrococcus } \\
\text { yunnanensis }\end{array}$ & Capsicum annum & $150 \mathrm{mM}$ & Seedling & $\begin{array}{l}\text { Increased dry root weight, } \\
\text { root length, dry shoot } \\
\text { weight, shoot length, } \\
\text { increased ACS activity } \\
\text { with decreased } \\
\text { ethylene synthesis }\end{array}$ & $\begin{array}{l}\text { Siddikee } \\
\text { et al. [237] }\end{array}$ \\
\hline $\begin{array}{c}\text { Burkholderia } \\
\text { cepacian, } \\
\text { Promicromonospora } \\
\text { sp., Acinetobacter } \\
\text { calcoaceticus }\end{array}$ & Cucumis sativus & $120 \mathrm{mM}$ & Seedling & $\begin{array}{c}\text { Significantly higher } \\
\text { biomass under salinity } \\
\text { stress, downregulated } \\
\text { ABA compared with } \\
\text { control plants, while } \\
\text { salicylic acid and } \\
\text { gibberellin } \mathrm{GA}_{4} \text { contents } \\
\text { were increased }\end{array}$ & Kang et al. [238] \\
\hline Pseudomonas putida & $\begin{array}{c}\text { Solanum } \\
\text { lycopersicum }\end{array}$ & $90 \mathrm{mM}$ & Seed & $\begin{array}{l}\text { Increased shoot growth } \\
\text { after } 6 \text { weeks in saline } \\
\text { conditions, expression of } \\
\text { Toc GTPase, a gene of the } \\
\text { chloroplast protein import } \\
\text { apparatus was } \\
\text { upregulated, which may } \\
\text { facilitate import of } \\
\text { proteins involved as a part } \\
\text { of stress response }\end{array}$ & Yan et al. [239] \\
\hline
\end{tabular}


Table 1. Cont.

\begin{tabular}{|c|c|c|c|c|c|}
\hline Bacteria Used & Plant & $\begin{array}{c}\text { Salt } \\
\text { Treatment }\end{array}$ & $\begin{array}{l}\text { Mode of } \\
\text { Treatment }\end{array}$ & Beneficial Effects & References \\
\hline $\begin{array}{l}\text { Bacillus } \\
\text { amyloliquefaciens }\end{array}$ & Zea mays & $100 \mathrm{mM}$ & Seedling & $\begin{array}{l}\text { Increased chlorophyll } \\
\text { content, total soluble } \\
\text { sugar content and } \\
\text { improved peroxidase and } \\
\text { catalase activity, } \\
\text { upregulation of genes } \\
\text { RBCS, RBCL (encoding } \\
\text { Ribulose } 1,5 \text {-bisphosphate } \\
\text { carboxylase/oxygenase } \\
\text { subunits), } \mathrm{H}^{+} \text {-PPase } \\
\text { (encoding } \mathrm{H}^{+} \text {pumping } \\
\text { pyrophosphatase), HKT1, } \\
\text { NHX1, NHX2 and NHX3 }\end{array}$ & Chen et al. [240] \\
\hline Enterobacter sp. & $\begin{array}{l}\text { Abelmoschus } \\
\text { esculentus }\end{array}$ & $75 \mathrm{mM}$ & Seedling & $\begin{array}{l}\text { Enhanced salt tolerance, } \\
\text { increased antioxidant } \\
\text { enzymes and transcription } \\
\text { of ROS pathway genes }\end{array}$ & Habib et al. [228] \\
\hline Herbaspirillum sp. & Brassica rapa & $150 \mathrm{mM}$ & Seedling & $\begin{array}{l}\text { Increased fresh and dry } \\
\text { root weight, fresh and dry } \\
\text { shoot weight }\end{array}$ & Lee et al. [241] \\
\hline Bacillus subtilis & $\begin{array}{l}\text { Puccinellia } \\
\text { tenuiflora }\end{array}$ & $200 \mathrm{mM}$ & Seed & $\begin{array}{l}\text { Reduced accumulation of } \\
\qquad \mathrm{Na}^{+} \text {ions }\end{array}$ & Niu et al. [242] \\
\hline Pantoea dispersa & Cicer arietinum & $\begin{array}{l}40 \mathrm{mM} \text { and } \\
60 \mathrm{mM}\end{array}$ & Seed & $\begin{array}{l}\text { Increased biomass, } \\
\text { number of pods and pod } \\
\text { weight, seed number and } \\
\text { seed weight, improved } \\
\text { chlorophyll content and } \\
\text { improved } \mathrm{K}^{+} \text {uptake }\end{array}$ & Panwar et al. [243] \\
\hline $\begin{array}{l}\text { Variovorax } \\
\text { paradoxus }\end{array}$ & Pisum sativum & $\begin{array}{l}70 \mathrm{mM} \text { and } \\
130 \mathrm{mM}\end{array}$ & Seedling & $\begin{array}{l}\text { Increased photosynthetic } \\
\text { rate, electron transport } \\
\text { with overall improvement } \\
\text { in the plant biomass, } \\
\text { increased root to shoot } \mathrm{K}^{+} \\
\text {flow and } \mathrm{Na}^{+} \text {deposition } \\
\text { in roots, thereby } \\
\text { increasing } \mathrm{K}^{+} / \mathrm{Na}^{+} \text {ratio } \\
\text { in shoots }\end{array}$ & Wang et al. [179] \\
\hline $\begin{array}{l}\text { Pseudomonas } \\
\text { fluorescens }\end{array}$ & Zea mays & $150 \mathrm{mM}$ & Seed & $\begin{array}{l}\text { Improved root growth and } \\
\text { promotion of root } \\
\text { formation, release of IAA } \\
\text { and protection against } \\
\text { inhibitory effects of } \mathrm{NaCl}\end{array}$ & Zerrouk et al. [244] \\
\hline $\begin{array}{c}\text { Microbacterium } \\
\text { oleivorans, } \\
\text { Brevibacterium } \\
\text { iodinum, Rickettsia } \\
\text { massiliae }\end{array}$ & Capsicum annum & $200 \mathrm{mM}$ & Seedling & $\begin{array}{l}\text { Increased fresh and dry } \\
\text { root weight, root length, } \\
\text { fresh and dry shoot } \\
\text { weight, shoot length, total } \\
\text { chlorophyll content, total } \\
\text { soluble sugar, proline } \\
\text { content and antioxidant } \\
\text { enzyme activity of APX, } \\
\text { CAT and GPX. }\end{array}$ & Hahm et al. [245] \\
\hline
\end{tabular}


Table 1. Cont.

\begin{tabular}{|c|c|c|c|c|c|}
\hline Bacteria Used & Plant & $\begin{array}{c}\text { Salt } \\
\text { Treatment }\end{array}$ & $\begin{array}{l}\text { Mode of } \\
\text { Treatment }\end{array}$ & Beneficial Effects & References \\
\hline Serratia liquefaciens & Zea mays & $\begin{array}{l}80 \mathrm{mM} \text { and } \\
160 \mathrm{mM}\end{array}$ & Z. mays plant & $\begin{array}{l}\text { Increased growth and } \\
\text { biomass yield, root length, } \\
\text { shoot length, root fresh } \\
\text { and dry weight, stem } \\
\text { fresh and dry weight, } \\
\text { chlorophyll content, } \\
\text { carotenoid content, total } \\
\text { soluble sugar and total } \\
\text { soluble protein }\end{array}$ & $\begin{array}{l}\text { El-Esawi } \\
\text { et al. [246] }\end{array}$ \\
\hline Klebsiella sp. & Avena sativa & $100 \mathrm{mM}$ & Seedling & $\begin{array}{l}\text { Increased fresh and dry } \\
\text { root weight, root length, } \\
\text { fresh and dry shoot } \\
\text { weight, enhanced biomass } \\
\text { with high } \\
\text { chlorophyll content }\end{array}$ & Sapre et al. [247] \\
\hline Enterobacter sp. & Oryza sativa & $150 \mathrm{mM}$ & Seedling & $\begin{array}{l}\text { Increased germination, } \\
\text { fresh and dry root weight, } \\
\text { root length, fresh and dry } \\
\text { shoot weight, shoot length, } \\
\text { chlorophyll content }\end{array}$ & Sarkar et al. [248] \\
\hline Burkholderia sp. & Oryza sativa & $185 \mathrm{mM}$ & Seedling & $\begin{array}{l}\text { Increased fresh and dry } \\
\text { root weight, number of } \\
\text { lateral branching roots } \\
\text { and root length, fresh and } \\
\text { dry shoot weight, } \\
\text { enhanced seed } \\
\text { germination, } \\
\text { chlorophyll content }\end{array}$ & Sarkar et al. [249] \\
\hline $\begin{array}{l}\text { Consortium of } \\
\text { Aneurinibacillus } \\
\text { aneurinilyticus and } \\
\text { Paenibacillus sp. }\end{array}$ & Phaseolus vulgaris & $25 \mathrm{mM}$ & Seed & $\begin{array}{l}\text { Increased shoot length, } \\
\text { root length with } \\
\text { chlorophyll content }\end{array}$ & $\begin{array}{c}\text { Gupta and Pandey } \\
\text { [199] }\end{array}$ \\
\hline Pseudomonas putida & Capsicum annuum & $\begin{array}{c}150 \mathrm{mM} \text { and } \\
300 \mathrm{mM}\end{array}$ & Seedling & $\begin{array}{l}\text { Increased fresh and dry } \\
\text { root weight, fresh and dry } \\
\text { shoot weight, nitrogen } \\
\text { and phosphorous } \\
\text { accumulation }\end{array}$ & He et al. [250] \\
\hline $\begin{array}{c}\text { Leclercia } \\
\text { adecarboxylata }\end{array}$ & $\begin{array}{c}\text { Solanum } \\
\text { lycopersicum }\end{array}$ & $120 \mathrm{mM}$ & Seedling & $\begin{array}{l}\text { Increased shoot length, } \\
\text { stem diameter, shoot } \\
\text { weight, root weight, } \\
\text { chlorophyll fluorescence, } \\
\text { sugar and amino } \\
\text { acid synthesis }\end{array}$ & Kang et al. [251] \\
\hline $\begin{array}{l}\text { Pseudomonas } \\
\text { plecoglossicida }\end{array}$ & Zea mays & $150 \mathrm{mM}$ & Seed & $\begin{array}{l}\text { Increased root length, } \\
\text { stem weight, stem height, } \\
\text { fresh and dry weight of } \\
\text { plant, chlorophyll content } \\
\text { and total } \\
\text { carbohydrate content }\end{array}$ & Zerrouk et al. [252] \\
\hline
\end{tabular}


Table 1. Cont.

\begin{tabular}{|c|c|c|c|c|c|}
\hline Bacteria Used & Plant & $\begin{array}{c}\text { Salt } \\
\text { Treatment }\end{array}$ & $\begin{array}{l}\text { Mode of } \\
\text { Treatment }\end{array}$ & Beneficial Effects & References \\
\hline $\begin{array}{l}\text { Azospirilum } \\
\text { lipoferum, Azobacter } \\
\text { chroococcum }\end{array}$ & Zea mays & $100 \mathrm{mM}$ & Seed & $\begin{array}{l}\text { Enhanced seedling leaf } \\
\text { area, increased fresh and } \\
\text { dry weight, chlorophyll } \\
\text { and carotenoid content, } \\
\text { total soluble sugar content } \\
\text { and total soluble } \\
\text { protein content }\end{array}$ & Latef et al. [253] \\
\hline $\begin{array}{c}\text { Stenotrophomonas } \\
\text { maltophilia }\end{array}$ & Arachis hypogea & $100 \mathrm{mM}$ & Plantlets & $\begin{array}{l}\text { Increased shoot length, } \\
\text { fresh and dry plant weight } \\
\text { and improved total } \\
\text { chlorophyll content }\end{array}$ & $\begin{array}{l}\text { Alexander } \\
\text { et al. [254] }\end{array}$ \\
\hline Kocuria rhizophila & Zea mays & $\begin{array}{l}100 \mathrm{mM} \text { and } \\
200 \mathrm{mM}\end{array}$ & Seed & $\begin{array}{l}\text { Increased root length, root } \\
\text { dry weight, shoot height, } \\
\text { shoot dry weight, } \\
\text { chlorophyll content, } \\
\text { soluble sugar content }\end{array}$ & Li et al. [255] \\
\hline $\begin{array}{l}\text { Pseudomonas } \\
\text { aeruginosa, } P . \\
\text { resinovorans }\end{array}$ & Eleusine coracana & $350 \mathrm{mM}$ & Seeds & $\begin{array}{l}\text { Increased germination, } \\
\text { vigor index, root length, } \\
\text { shoot length, improved } \\
\text { number of spikelets }\end{array}$ & $\begin{array}{c}\text { Mahadik et al. } \\
\text { [256] }\end{array}$ \\
\hline Bacillus safensis & Zea mays & $100 \mathrm{mM}$ & Seedling & $\begin{array}{l}\text { Increased root length, } \\
\text { shoot length, fresh and dry } \\
\text { weight of plant, number of } \\
\text { leaves, chlorophyll and } \\
\text { carotenoid content and } \\
\text { total soluble sugar content }\end{array}$ & $\begin{array}{c}\text { Misra and } \\
\text { Chauhan [257] }\end{array}$ \\
\hline $\begin{array}{l}\text { Sphingobacterium } \\
\text { sp. }\end{array}$ & $\begin{array}{l}\text { Lycopersicum } \\
\text { esculentum }\end{array}$ & $200 \mathrm{mM}$ & Seed & $\begin{array}{l}\text { Enhanced plant biomass, } \\
\text { root length, and shoot } \\
\text { length, production of IAA } \\
\text { and siderophores, } \\
\text { phosphate solubilization }\end{array}$ & $\begin{array}{c}\text { Vaishnav et al. } \\
\text { [258] }\end{array}$ \\
\hline $\begin{array}{l}\text { Pseudomonas } \\
\text { migulae }\end{array}$ & Camelina sativa & 192 and $213 \mathrm{mM}$ & Soil & $\begin{array}{l}\text { Reduced the decline in } \\
\text { shoot length, shoot weight } \\
\text { and photosynthetic } \\
\text { capacity, negatively } \\
\text { affected ethylene } \\
\text { signaling, auxin and JA } \\
\text { biosynthesis and } \\
\text { signaling, and positive } \\
\text { effect on the regulation of } \\
\text { genes in GA signaling }\end{array}$ & $\begin{array}{l}\text { Heydarian } \\
\text { et al. [72] }\end{array}$ \\
\hline
\end{tabular}




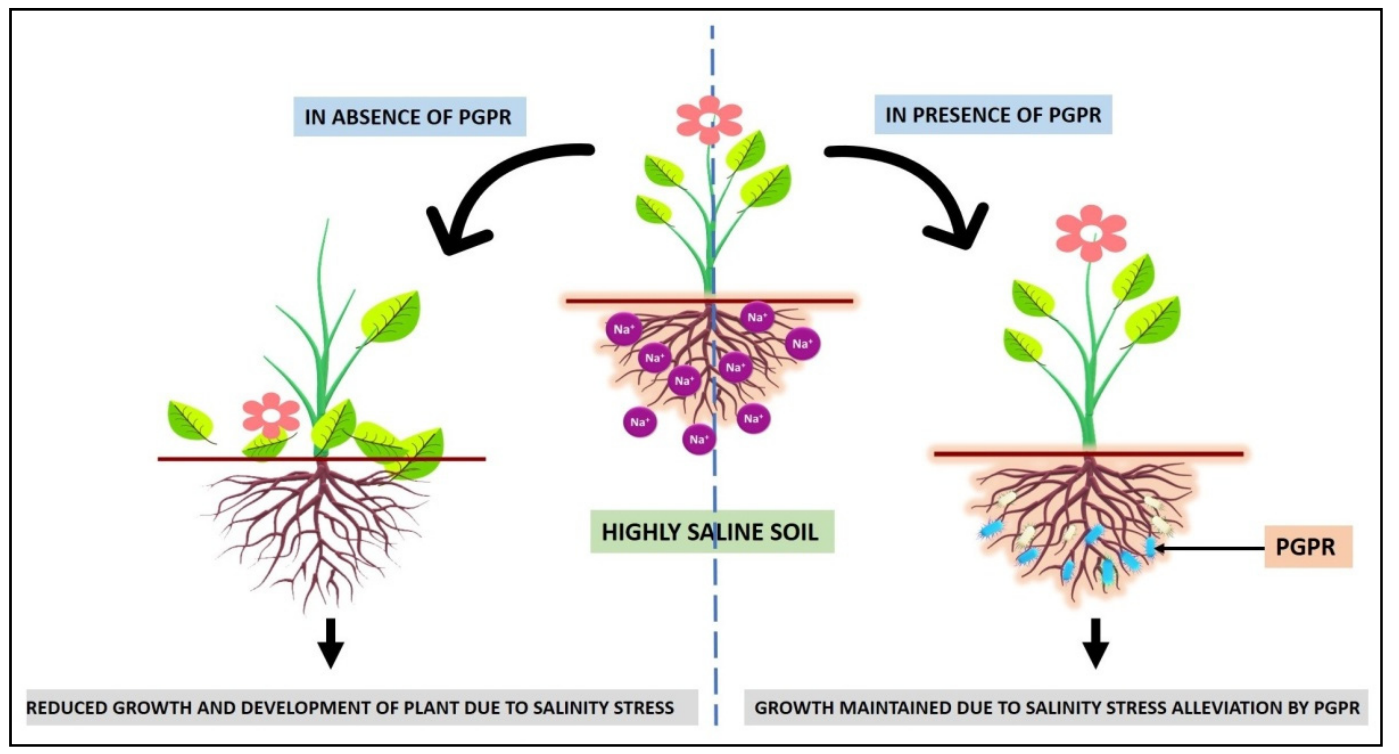

Figure 8. Effect of salinity on plants with and without the association of PGPR.

\section{Conclusions and Future Prospects}

Soil salinity is one of the key abiotic stressors that reduce agricultural output by slowing plant growth. One reason for this could be the growing use of chemical fertilizers, which negatively modify soil composition. Plants have their mechanisms for dealing with salinity stress, but in many cases, these processes are insufficient to keep plant growth and development from being considerably hampered. Several strategies for reducing saline stress in agriculture, including chemical and physical treatment of seeds before planting and sustainable agricultural management practices, have helped reduce the effects of excessive salt accumulation in soil. Fortunately, all plants interact with microorganisms in the rhizosphere, phyllosphere, and endosphere, positively impacting plant growth. The PGPR is of special interest to crops because it includes many beneficial mechanisms, including ACC deaminase, which can boost plant tolerance to salt stress by cleaving ACC, a direct precursor of ethylene. The importance of ACC deaminase activity in bacterial strains reduces ethylene levels in plants under salinity stress has been well recognized. Undoubtedly, PGPR with ACC deaminase activity (among other mechanisms) is a viable approach for improving crop quality and yield in saline soils.

Author Contributions: Conceptualization, K.N.A., A.C.U., M.A.A. and S.R.N.; methodology, D.V.B., A.K. (Asha Kiran) and J.K.K.; software and validation, M.M., S.A., H.A., A.K. (Ahmed Kabrah); formal analysis, L.S.N., C.K.P. and A.C.U.; investigation, D.V.B., A.K. (Asha Kiran), A.S.D. and K.N.A.; resources, K.N.A., A.C.U., M.A.A. and S.R.N.; data curation, A.S.D. and M.M.; writingoriginal draft preparation, D.V.B., A.K. (Asha Kiran) and J.K.K. writing-review and editing, M.M. and M.A.A.; visualization, A.S.D., A.K. (Ahmed Kabrah) and H.A.; supervision, A.C.U., M.A.A. and S.R.N.; project administration, S.R.N.; funding acquisition, M.M., A.C.U. and M.A.A. All authors have read and agreed to the published version of the manuscript.

Funding: This work was funded by Deanship of Scientific Research Project number (2019-091-IRMC), Imam Abdulrahman Bin Faisal University, Dammam, Saudi Arabia.

Institutional Review Board Statement: Not applicable.

Informed Consent Statement: Not applicable.

Data Availability Statement: The data presented in this study are available in this manuscript.

Acknowledgments: The authors thank the Department of Studies in Botany and Department of Studies in Biotechnology, University of Mysore, Mysuru, for providing facilities to carry out research. In addition, Murali, M., thanks the University Grants Commission (UGC), New Delhi, 
India, for providing financial support under UGC Postdoctoral Fellowship for SC/ST Candidates (No. F/PDFSS-2015-17-KAR-11846). We would also like to acknowledge Naveen Kumar, Gowtham, H.G. and Brijesh Singh for their kind inputs during the preparation of manuscript.

Conflicts of Interest: The authors declare no conflict of interest.

\section{References}

1. Gonzalez, N.; Vanhaeren, H.; Inzé, D. Leaf size control: Complex coordination of cell division and expansion. Trends Plant Sci. 2012, 17, 332-340. [CrossRef] [PubMed]

2. Murali, M.; Amruthesh, K.N. Plant Growth-promoting Fungus Penicillium oxalicum enhances plant growth and induces resistance in pearl millet against downy mildew disease. J. Phytopathol. 2015, 163, 743-754. [CrossRef]

3. Gull, A.; Lone, A.A.; Wani, N.U.I. Biotic and abiotic stresses in plants. In Abiotic and Biotic Stress in Plants; IntechOpen Book Series: London, UK, 2019; pp. 1-19. [CrossRef]

4. Mosa, K.A.; Ismail, A.; Helmy, M. Introduction to plant stresses. In Plant Stress Tolerance; Springer: Cham, Switzerland, 2017; pp. 1-19. [CrossRef]

5. Murali, M.; Brijesh Singh, S.; Gowtham, H.G.; Shilpa, N.; Prasad, M.; Aiyaz, M.; Amruthesh, K.N. Induction of drought tolerance in Pennisetum glaucum by ACC deaminase producing PGPR- Bacillus amyloliquefaciens through Antioxidant defense system. Microbiol. Res. 2021, 253, 126891. [CrossRef]

6. Nadeem, S.M.; Zahir, Z.A.; Naveed, M.; Ashraf, M. Microbial ACC-deaminase: Prospects and applications for inducing salt tolerance in plants. Crit. Rev. Plant Sci. 2010, 29, 360-393. [CrossRef]

7. Waqas, M.A.; Kaya, C.; Riaz, A.; Farooq, M.; Nawaz, I.; Wilkes, A.; Li, Y. Potential mechanisms of abiotic stress tolerance in crop plants induced by thiourea. Front. Plant Sci. 2019, 10, 1336. [CrossRef]

8. Dos Reis, S.P.; Lima, A.M.; De Souza, C.R.B. Recent molecular advances on downstream plant responses to abiotic stress. Int. J. Mol. Sci. 2012, 13, 8628-8647. [CrossRef]

9. Mantri, N.; Patade, V.; Penna, S.; Ford, R.; Pang, E. Abiotic stress responses in plants: Present and future. In Abiotic Stress Responses in Plants; Ahmad, P., Prasad, M., Eds.; Springer: New York, NY, USA, 2012; pp. 1-19. [CrossRef]

10. Singh, B.; Gowtham, H.G.; Niranjana, S.R. ACC deaminase producing PGPR invoke changes in antioxidant systems to minimize the adverse effects of salt in sunflower. RJLBPCS 2019, 5, 1-15. [CrossRef]

11. Sah, S.K.; Reddy, K.R.; Li, J. Abscisic acid and abiotic stress tolerance in crop plants. Front. Plant Sci. 2016, 7, 571. [CrossRef] [PubMed]

12. Munns, R.; Tester, M. Mechanisms of salinity tolerance. Annu. Rev. Plant Biol. 2008, 59, 651-681. [CrossRef]

13. Qadir, M.; Quillérou, E.; Nangia, V.; Murtaza, G.; Singh, M.; Thomas, R.J.; Drechsel, P.; Noble, A.D. Economics of salt-induced land degradation and restoration. Nat. Resour. Forum 2014, 38, 282-295. [CrossRef]

14. James, R.A.; Blake, C.; Byrt, C.S.; Munns, R. Major genes for Na ${ }^{+}$exclusion, Nax1 and Nax2 (wheat HKT1; 4 and HKT1; 5), decrease $\mathrm{Na}^{+}$accumulation in bread wheat leaves under saline and waterlogged conditions. J. Exp. Bot. 2011, 62, 2939-2947. [CrossRef]

15. Rahnama, A.; James, R.A.; Poustini, K.; Munns, R. Stomatal conductance as a screen for osmotic stress tolerance in durum wheat growing in saline soil. Funct. Plant Biol. 2010, 37, 255-263. [CrossRef]

16. Singh, V.K.; Singh, A.K.; Kumar, A. Disease management of tomato through PGPB: Current trends and future perspective. 3 Biotech 2017, 7, 1-10. [CrossRef]

17. Glick, B.R. Modulation of plant ethylene levels by the bacterial enzyme ACC deaminase. FEMS Microbiol. Lett. 2005, 251, 1-7. [CrossRef] [PubMed]

18. Brijesh Singh, S.; Gowtham, H.G.; Murali, M.; Hariprasad, P.; Lakshmeesha, T.R.; Murthy, K.N.; Amruthesh, K.N.; Niranjana, S.R. Plant growth promoting ability of ACC deaminase producing rhizobacteria native to Sunflower (Helianthus annuus L.). Biocatal. Agric. Biotechnol. 2019, 18, 101089. [CrossRef]

19. Gowtham, H.G.; Brijesh Singh, S.; Murali, M.; Shilpa, N.; Prasad, M.; Aiyaz, M.; Amruthesh, K.N.; Niranjana, S.R. Induction of drought tolerance in tomato upon the application of ACC deaminase producing plant growth promoting rhizobacterium Bacillus subtilis Rhizo SF 48. Microbiol. Res. 2020, 234, 126422. [CrossRef]

20. Murali, M.; Gowtham, H.G.; Brijesh Singh, S.; Shilpa, N.; Aiyaz, M.; Niranjana, S.R.; Amruthesh, K.N. Bio-prospecting of ACC deaminase producing Rhizobacteria towards sustainable agriculture: A special emphasis on abiotic stress in plants. Appl. Soil Ecol. 2021, 168, 104142. [CrossRef]

21. Gamalero, E.; Glick, B.R. Bacterial modulation of plant ethylene levels. Plant Physiol. 2015, 169, 13-22. [CrossRef] [PubMed]

22. Grover, M.; Ali, S.Z.; Sandhya, V.; Rasul, A.; Venkateswarlu, B. Role of microorganisms in adaptation of agriculture crops to abiotic stresses. World J. Microbiol. Biotechnol. 2011, 27, 1231-1240. [CrossRef]

23. Munns, R.; Gilliham, M. Salinity tolerance of crops-What is the cost? New Phytol. 2015, 208, 668-673. [CrossRef] [PubMed]

24. Takahashi, F.; Tilbrook, J.; Trittermann, C.; Berger, B.; Roy, S.J.; Seki, M.; Shinozaki, K.; Tester, M. Comparison of Leaf Sheath Transcriptome Profiles with Physiological Traits of Bread Wheat Cultivars under Salinity Stress. PLoS ONE 2015, 10, e0133322. [CrossRef] [PubMed]

25. Deinlein, U.; Stephan, A.B.; Horie, T.; Luo, W.; Xu, G.; Schroeder, J.I. Plant salt-tolerance mechanisms. Trends Plant Sci. 2014, 19, 371-379. [CrossRef] [PubMed] 
26. Yang, Y.; Guo, Y. Elucidating the molecular mechanisms mediating plant salt-stress responses. New Phytol. 2018, 217, 523-539. [CrossRef]

27. Hasegawa, P.M.; Bressan, R.A.; Zhu, J.-K.; Bohnert, H.J. Plant cellular and molecular responses to high salinity. Annu. Rev. Plant Physiol. Plant Mol. Biol. 2000, 51, 463-499. [CrossRef] [PubMed]

28. Tuteja, N. Mechanisms of high salinity tolerance in plants. Methods Enzymol. 2007, 428, 419-438. [CrossRef]

29. Singhal, R.; Chauhan, J. Calmodulin in Plant Responses to Abiotic Stresses and Signalling. Int. J. Pure App. Biosci. 2017, 5, 1122-1131. [CrossRef]

30. Noctor, G.; Reichheld, J.-P.; Foyer, C.H. ROS-related redox regulation and signaling in plants. Semin. Cell Dev. Biol. 2018, 80, 3-12. [CrossRef]

31. Poustini, K.; Siosemardeh, A. Ion distribution in wheat cultivars in response to salinity stress. Field Crop. Res. 2004, 85, 125-133. [CrossRef]

32. James, R.A.; Davenport, R.J.; Munns, R. Physiological characterization of two genes for $\mathrm{Na}^{+}$exclusion in durum wheat, Nax1 and Nax2. Plant physiology 2006, 142, 1537-1547. [CrossRef]

33. Miller, G.; Suzuki, N.; Ciftci-Yilmaz, S.; Mittler, R. Reactive oxygen species homeostasis and signalling during drought and salinity stresses. Plant Cell Environ. 2010, 33, 453-467. [CrossRef] [PubMed]

34. Chaves, M.M.; Flexas, J.; Pinheiro, C. Photosynthesis under drought and salt stress: Regulation mechanisms from whole plant to cell. Ann. Bot. 2009, 103, 551-560. [CrossRef] [PubMed]

35. Yan, K.; Shao, H.; Shao, C.; Chen, P.; Zhao, S.; Brestic, M.; Chen, X. Physiological adaptive mechanisms of plants grown in saline soil and implications for sustainable saline agriculture in coastal zone. Acta Physiol. Plant. 2013, 35, 2867-2878. [CrossRef]

36. Mbarki, S.; Sytar, O.; Cerda, A.; Zivcak, M.; Rastogi, A.; He, X.; Zoghlami, A.; Abdelly, C.; Brestic, M. Strategies to Mitigate the Salt Stress Effects on Photosynthetic Apparatus and Productivity of Crop Plants. In Salinity Responses and Tolerance in Plants, Volume 1: Targeting Sensory, Transport and Signaling Mechanisms; Springer: Cham, Switzerland, 2018; pp. 85-136. [CrossRef]

37. Meng, F.; Luo, Q.; Wang, Q.; Zhang, X.; Qi, Z.; Xu, F.; Lei, X.; Cao, Y.; Chow, W.S.; Sun, G. Physiological and proteomic responses to salt stress in chloroplasts of diploid and tetraploid black locust (Robiniapseudoacacia L.). Sci. Rep. 2016, 6, 1-15. [CrossRef]

38. Kwon, O.K.; Mekapogu, M.; Kim, K.S. Effect of salinity stress on photosynthesis and related physiological responses in carnation (Dianthus caryophyllus). Hortic. Environ. Biotechnol. 2019, 60, 831-839. [CrossRef]

39. Mousavi, S.; Regni, L.; Bocchini, M.; Mariotti, R.; Cultrera, N.G.; Mancuso, S.; Googlani, J.; Chakerolhosseini, M.R.; Guerrero, C.; Albertini, E.; et al. Physiological, epigenetic and genetic regulation in some olive cultivars under salt stress. Sci. Rep. 2019, 9, 1-17. [CrossRef]

40. RajabiDehnavi, A.; Zahedi, M.; Ludwiczak, A.; Cardenas Perez, S.; Piernik, A. Effect of salinity on seed germination and seedling development of sorghum (Sorghum bicolor (L.) Moench) genotypes. Agronomy 2020, 10, 859. [CrossRef]

41. Shrivastava, P.; Kumar, R. Soil salinity: A serious environmental issue and plant growth promoting bacteria as one of the tools for its alleviation. Saudi J. Biol. Sci. 2015, 22, 123-131. [CrossRef] [PubMed]

42. Munns, R. Genes and salt tolerance: Bringing them together. New Phytol. 2005, 167, 645-663. [CrossRef]

43. Egamberdieva, D.; Wirth, S.; Bellingrath-Kimura, S.D.; Mishra, J.; Arora, N.K. Salt-tolerant plant growth promoting rhizobacteria for enhancing crop productivity of saline soils. Front. Microbiol. 2019, 10, 2791. [CrossRef] [PubMed]

44. Ali, Y.; Aslam, Z.; Ashraf, M.Y.; Tahir, G.R. Effect of salinity on chlorophyll concentration, leaf area, yield and yield components of rice genotypes grown under saline environment. Int. J. Environ. Sci. Technol. 2004, 1, 221-225. [CrossRef]

45. Abdel-Farid, I.B.; Marghany, M.R.; Rowezek, M.M.; Sheded, M.G. Effect of salinity stress on growth and metabolomic profiling of Cucumis sativus and Solanum lycopersicum. Plants 2020, 9, 1626. [CrossRef] [PubMed]

46. Gupta, S.; Schillaci, M.; Walker, R.; Smith, P.M.; Watt, M.; Roessner, U. Alleviation of salinity stress in plants by endophytic plant-fungal symbiosis: Current knowledge, perspectives and future directions. Plant Soil 2021, 461, 219-244. [CrossRef]

47. Balliu, A.; Sallaku, G.; Rewald, B. AMF inoculation enhances growth and improves the nutrient uptake rates of transplanted, salt-stressed tomato seedlings. Sustainability 2015, 7, 15967-15981. [CrossRef]

48. Negrão, S.; Schmöckel, S.M.; Tester, M. Evaluating physiological responses of plants to salinity stress. Ann. Bot. 2017, 119, 1-11. [CrossRef] [PubMed]

49. Acosta-Motos, J.R.; Ortuño, M.F.; Bernal-Vicente, A.; Diaz-Vivancos, P.; Sanchez-Blanco, M.J.; Hernandez, J.A. Plant responses to salt stress: Adaptive mechanisms. Agronomy 2017, 7, 18. [CrossRef]

50. Khan, M.A.; Shaukat, S.S.; Shahzad, A.; Arif, H. Growth and yield responses of pearl millet (Pennisetum glaucum [L.] R. Br.) irrigated with treated effluent from waste stabilization ponds. Pak. J. Bot. 2012, 44, 905-910.

51. Läuchli, A.; Grattan, S.R. Plant growth and development under salinity stress. In Advances in Molecular Breeding Toward Drought and Salt Tolerant Crops; Jenks, M.A., Hasegawa, P.M., Jain, S.M., Eds.; Springer: Dordrecht, The Netherlands, 2007 ; pp. 1-32. [CrossRef]

52. Yang, Z.; Li, J.L.; Liu, L.N.; Xie, Q.; Sui, N. Photosynthetic regulation under salt stress and salt-tolerance mechanism of sweet sorghum. Front. Plant Sci. 2020, 10, 1722. [CrossRef]

53. Ashraf, M.H.P.J.C.; Harris, P.J. Photosynthesis under stressful environments: An overview. Photosynthetica 2013, 51, 163-190. [CrossRef]

54. Waszczak, C.; Carmody, M.; Kangasjärvi, J. Reactive Oxygen Species in Plant Signaling. Annu. Rev. Plant Biol. 2018, 69, 209-236. [CrossRef] 
55. Allakhverdiev, S.I.; Murata, N. Environmental stress inhibits the synthesis de novo of proteins involved in the photodamage-repair cycle of photosystem II in Synechocystis sp. PCC 6803. BBA-Bioenerg. 2004, 1657, 23-32. [CrossRef]

56. Tahjib-UI-Arif, M.; Sohag, A.A.M.; Afrin, S.; Bashar, K.K.; Afrin, T.; Mahamud, A.G.M.; Polash, M.A.S.; Hossain, M.; Sohel, M.; Taher, A.; et al. Differential Response of Sugar Beet to Long-Term Mild to Severe Salinity in a Soil-Pot Culture. Agriculture 2019, 9 , 223. [CrossRef]

57. Pinheiro, H.A.; Silva, J.V.; Endres, L.; Ferreira, V.M.; de Albuquerque Câmara, C.; Cabral, F.F.; Oliveira, J.F.; de Carvalho, L.W.T.; dos Santos, J.M.; dos Santos Filho, B.G. Leaf gas exchange, chloroplastic pigments and dry matter accumulation in castor bean (Ricinus communis L) seedlings subjected to salt stress conditions. Ind. Crop. Prod. 2008, 27, 385-392. [CrossRef]

58. Li, T.Y.; Zhang, Y.; Liu, H.; Wu, Y.; Li, W.; Zhang, H. Stable expression of Arabidopsis vacuolar $\mathrm{Na}^{+} / \mathrm{H}^{+}$antiporter gene AtNHX1, and salt tolerance in transgenic soybean for over six generations. Chin. Sci. Bull. 2010, 55, 1127-1134. [CrossRef]

59. Yang, J.Y.; Zheng, W.; Tian, Y.; Wu, Y.; Zhou, D.W. Effects of various mixed salt-alkaline stresses on growth, photosynthesis, and photosynthetic pigment concentrations of Medicago ruthenica seedlings. Photosynthetica 2011, 49, 275-284. [CrossRef]

60. Santos, C.V. Regulation of chlorophyll biosynthesis and degradation by salt stress in sunflower leaves. Sci. Hortic. 2004, 103, 93-99. [CrossRef]

61. Akram, M.S.; Ashraf, M. Exogenous application of potassium dihydrogen phosphate can alleviate the adverse effects of salt stress on sunflower. J. Plant Nutr. 2011, 34, 1041-1057. [CrossRef]

62. Lin, J.; Li, J.P.; Yuan, F.; Yang, Z.; Wang, B.S.; Chen, M. Transcriptome profiling of genes involved in photosynthesis in Elaeagnus angustifolia L. under salt stress. Photosynthetica 2018, 56, 998-1009. [CrossRef]

63. Juan, M.; Rivero, R.M.; Romero, L.; Ruiz, J.M. Evaluation of some nutritional and biochemical indicators in selecting salt-resistant tomato cultivars. Environ. Exp. Bot. 2005, 54, 193-201. [CrossRef]

64. Flowers, T.J.; Troke, P.F.; Yeo, A.R. The mechanism of salt tolerance in halophytes. Annu. Rev. Plant Physiol. 1977, $28,89-121$. [CrossRef]

65. Choudhury, F.K.; Rivero, R.M.; Blumwald, E.; Mittler, R. Reactive oxygen species, abiotic stress and stress combination. Plant J. 2017, 90, 856-867. [CrossRef]

66. Geissler, N.; Hussin, S.; Koyro, H.W. Elevated atmospheric $\mathrm{CO}_{2}$ concentration ameliorates effects of $\mathrm{NaCl}$ salinity on photosynthesis and leaf structure of Aster tripolium L. J. Exp. Bot. 2009, 60, 137-151. [CrossRef] [PubMed]

67. Balouchi, H.R. Screening wheat parents of mapping population for heat and drought tolerance, detection of wheat genetic variation. Int. J. Biol. Life Sci. 2010, 6. [CrossRef]

68. Vaz, J.; Sharma, P.K. Relationship between xanthophyll cycle and non-photochemical quenching in rice (Oryza sativa L.) plants in response to light stress. Indian J. Exp. Biol. 2011, 49, 60-67. [PubMed]

69. Flowers, T.J.; Duque, E.; Hajibagheri, M.A.; McGonigle, T.P.; Yeo, A.R. The effect of salinity on leaf ultrastructure and net photosynthesis of two varieties of rice: Further evidence for a cellular component of salt-resistance. New Phytol. 1985, 100, 37-43. [CrossRef]

70. Hernandez, J.A.; Olmos, E.; Corpas, F.J.; Sevilla, F.; Del Rio, L.A. Salt-induced oxidative stress in chloroplasts of pea plants. Plant Sci. 1995, 105, 151-167. [CrossRef]

71. Austin, J.R.; Frost, E.; Vidi, P.A.; Kessler, F.; Staehelin, L.A. Plastoglobules are lipoprotein subcompartments of the chloroplast that are permanently coupled to thylakoid membranes and contain biosynthetic enzymes. Plant Cell 2006, 18, 1693-1703. [CrossRef] [PubMed]

72. Heydarian, Z.; Gruber, M.; Coutu, C.; Glick, B.R.; Hegedus, D.D. Gene expression patterns in shoots of Camelina sativa with enhanced salinity tolerance provided by plant growth promoting bacteria producing 1-aminocyclopropane-1-carboxylate deaminase or expression of the corresponding acdS gene. Sci. Rep. 2021, 11, 1-15. [CrossRef]

73. Zhao, C.; Zhang, H.; Song, C.; Zhu, J.K.; Shabala, S. Mechanisms of plant responses and adaptation to soil salinity. Innovation 2020, 1, 100017. [CrossRef] [PubMed]

74. Tuteja, N. Abscisic acid and abiotic stress signaling. Plant Signal. Behav. 2007, 2, 135-138. [CrossRef]

75. Swamy, P.M.; Smith, B.N. Role of abscisic acid in plant stress tolerance. Curr. Sci. 1999, 76, 1220-1227.

76. Jia, W.; Wang, Y.; Zhang, S.; Zhang, J. Salt-stress-induced ABA accumulation is more sensitively triggered in roots than in shoots. J. Exp. Bot. 2002, 53, 2201-2206. [CrossRef]

77. Fricke, W.; Akhiyarova, G.; Veselov, D.; Kudoyarova, G. Rapid and tissue-specific changes in ABA and in growth rate in response to salinity in barley leaves. J. Exp. Bot. 2004, 55, 1115-1123. [CrossRef]

78. Xing, Y.; Jia, W.; Zhang, J. AtMKK1 mediates ABA-induced CAT1 expression and $\mathrm{H}_{2} \mathrm{O}_{2}$ production via AtMPK6-coupled signaling in Arabidopsis. Plant J. Cell Mol. Biol. 2008, 54, 440-451. [CrossRef] [PubMed]

79. Osakabe, Y.; Yamaguchi-Shinozaki, K.; Shinozaki, K.; Tran, L.S.P. ABA control of plant macroelement membrane transport systems in response to water deficit and high salinity. New Phytol. 2014, 202, 35-49. [CrossRef] [PubMed]

80. Ma, Y.; Szostkiewicz, I.; Korte, A.; Moes, D.; Yang, Y.; Christmann, A.; Grill, E. Regulators of PP2C phosphatase activity function as abscisic acid sensors. Science 2009, 324, 1064-1068. [CrossRef] [PubMed]

81. Park, S.Y.; Fung, P.; Nishimura, N.; Jensen, D.R.; Fujii, H.; Zhao, Y.; Lumba, S.; Santiago, J.; Rodrigues, A.; Tsz-fung, F.C.; et al. Abscisic acid inhibits type 2C protein phosphatases via the PYR/PYL family of START proteins. Science 2009, 324, $1068-1071$. [CrossRef] [PubMed] 
82. Geiger, D.; Scherzer, S.; Mumm, P.; Stange, A.; Marten, I.; Bauer, H.; Ache, P.; Matschi, S.; Liese, A.; Al-Rasheid, K.A.; et al. Activity of guard cell anion channel SLAC1 is controlled by drought-stress signaling kinase-phosphatase pair. Proc. Natl. Acad. Sci. USA 2009, 106, 21425-21430. [CrossRef] [PubMed]

83. Hubbard, K.E.; Nishimura, N.; Hitomi, K.; Getzoff, E.D.; Schroeder, J.I. Early abscisic acid signal transduction mechanisms: Newly discovered components and newly emerging questions. Genes Dev. 2010, 24, 1695-1708. [CrossRef] [PubMed]

84. Wang, J.; Song, L.; Gong, X.; Xu, J.; Li, M. Functions of jasmonic acid in plant regulation and response to abiotic stress. Int. J. Mol. Sci. 2020, 21, 1446. [CrossRef]

85. Ruan, J.; Zhou, Y.; Zhou, M.; Yan, J.; Khurshid, M.; Weng, W.; Cheng, J.; Zhang, K. Jasmonic acid signaling pathway in plants. Int. J. Mol. Sci. 2019, 20, 2479. [CrossRef]

86. Abouelsaad, I.; Renault, S. Enhanced oxidative stress in the jasmonic acid-deficient tomato mutant def- 1 exposed to NaCl stress. J. Plant Physiol. 2018, 226, 136-144. [CrossRef] [PubMed]

87. Shahzad, A.N.; Pitann, B.; Ali, H.; Qayyum, M.F.; Fatima, A.; Bakhat, H.F. Maize genotypes differing in salt resistance vary in jasmonic acid accumulation during the first phase of salt stress. J. Agron. Crop Sci. 2015, 201, 443-451. [CrossRef]

88. Bandurska, H.; Stroiński, A.; Kubiś, J. The effect of jasmonic acid on the accumulation of ABA, proline and spermidine and its influence on membrane injury under water deficit in two barley genotypes. Acta Physiol. Plant. 2003, 25, 279-285. [CrossRef]

89. Walia, H.; Wilson, C.; Condamine, P.; Liu, X.; Ismail, A.M.; Close, T.J. Large-scale expression profiling and physiological characterization of jasmonic acid-mediated adaptation of barley to salinity stress. Plant Cell Environ. 2007, 30, 410-421. [CrossRef]

90. Rout, S.; Beura, S.; Khare, N.; Patra, S.S.; Nayak, S. Effect of seed pre-treatment with different concentrations of gibberellic acid $\left(\mathrm{GA}_{3}\right)$ on seed germination and seedling growth of Cassia fistula L. Plants Stud. 2017, 5, 135-138.

91. Achard, P.; Cheng, H.; De Grauwe, L.; Decat, J.; Schoutteten, H.; Moritz, T.; Van Der Straeten, D.; Peng, J.; Harberd, N.P. Integration of plant responses to environmentally activated phytohormonal signals. Science 2006, 311, 91-94. [CrossRef] [PubMed]

92. Shekafandeh, A.; Sirooeenejad, S.; Alsmoushtaghi, E. Influence of gibberellin on increasing of sodium chloride tolerance via some morpho-physiological changes in two olive cultivars. Agric. Conspec. Sci. 2017, 82, 367-373.

93. Kaya, C.; Tuna, A.L.; Yokaş, I. The role of plant hormones in plants under salinity stress. In Salinity and Water Stress; Ashraf, M., Ozturk, M., Athar, H., Eds.; Springer: Dordrecht, The Netherlands, 2009; pp. 45-50. [CrossRef]

94. Riyazuddin, R.; Verma, R.; Singh, K.; Nisha, N.; Keisham, M.; Bhati, K.K.; Kim, S.T.; Gupta, R. Ethylene: A master regulator of salinity stress tolerance in plants. Biomolecules 2020, 10, 959. [CrossRef]

95. Cao, W.H.; Liu, J.; He, X.J.; Mu, R.L.; Zhou, H.L.; Chen, S.Y.; Zhang, J.S. Modulation of ethylene responses affects plant salt-stress responses. Plant Physiol. 2007, 143, 707-719. [CrossRef]

96. Peng, Z.; He, S.; Gong, W.; Sun, J.; Pan, Z.; Xu, F.; Lu, Y.; Du, X. Comprehensive analysis of differentially expressed genes and transcriptional regulation induced by salt stress in two contrasting cotton genotypes. BMC Genom. 2014, 15, 1-28. [CrossRef]

97. Arfan, M.; Athar, H.R.; Ashraf, M. Does exogenous application of salicylic acid through the rooting medium modulate growth and photosynthetic capacity in two differently adapted spring wheat cultivars under salt stress? J. Plant Physiol. 2007, 164, 685-694. [CrossRef]

98. Xu, Q.; Xu, X.; Zhao, Y.; Jiao, K.; Herbert, S.J.; Hao, L. Salicylic acid, hydrogen peroxide and calcium-induced saline tolerance associated with endogenous hydrogen peroxide homeostasis in naked oat seedlings. Plant Growth Regul. 2008, 54, 249-259. [CrossRef]

99. Gunes, A.; Inal, A.; Alpaslan, M.; Eraslan, F.; Bagci, E.G.; Cicek, N. Salicylic acid induced changes on some physiological parameters symptomatic for oxidative stress and mineral nutrition in maize (Zea mays L.) grown under salinity. J. Plant Physiol. 2007, 164, 728-736. [CrossRef] [PubMed]

100. Nazar, R.; Iqbal, N.; Syeed, S.; Khan, N.A. Salicylic acid alleviates decreases in photosynthesis under salt stress by enhancing nitrogen and sulfur assimilation and antioxidant metabolism differentially in two mungbean cultivars. J. Plant Physiol. 2011, 168, 807-815. [CrossRef] [PubMed]

101. Poór, P.; Gémes, K.; Horváth, F.; Szepesi, A.; Simon, M.L.; Tari, I. Salicylic acid treatment via the rooting medium interferes with stomatal response, $\mathrm{CO}_{2}$ fixation rate and carbohydrate metabolism in tomato, and decreases harmful effects of subsequent salt stress. Plant Biol. 2011, 13, 105-114. [CrossRef] [PubMed]

102. Szepesi, Á.; Csiszár, J.; Gémes, K.; Horváth, E.; Horváth, F.; Simon, M.L.; Tari, I. Salicylic acid improves acclimation to salt stress by stimulating abscisic aldehyde oxidase activity and abscisic acid accumulation, and increases $\mathrm{Na}^{+}$content in leaves without toxicity symptoms in Solanum lycopersicum L. J. Plant Physiol. 2009, 166, 914-925. [CrossRef]

103. Iglesias, M.J.; Terrile, M.C.; Casalongué, C.A. Auxin and salicylic acid signalings counteract the regulation of adaptive responses to stress. Plant Signal. Behav. 2011, 6, 452-454. [CrossRef]

104. Kováčik, J.; Klejdus, B.; Hedbavny, J.; Bačkor, M. Salicylic acid alleviates NaCl-induced changes in the metabolism of Matricaria chamomilla plants. Ecotoxicology 2009, 18, 544-554. [CrossRef] [PubMed]

105. Misra, N.; Misra, R. Salicylic acid changes plant growth parameters and proline metabolism in Rauwolfia serpentina leaves grown under salinity stress. Am. Eurasian J. Agric. Environ. Sci. 2012, 12, 1601-1609.

106. Niu, L.; Liao, W. Hydrogen peroxide signaling in plant development and abiotic responses: Crosstalk with nitric oxide and calcium. Front. Plant Sci. 2016, 7, 230. [CrossRef]

107. Fancy, N.N.; Bahlmann, A.K.; Loake, G.J. Nitric oxide function in plant abiotic stress. Plant Cell Environ. 2017, 40, 462-472. [CrossRef] [PubMed] 
108. Ahmad, P.; Ahanger, M.A.; Alyemeni, M.N.; Wijaya, L.; Alam, P. Exogenous application of nitric oxide modulates osmolyte metabolism, antioxidants, enzymes of ascorbate glutathione cycle and promotes growth under cadmium stress in tomato. Protoplasma 2018, 255, 79-93. [CrossRef]

109. Nabi, R.B.S.; Tayade, R.; Hussain, A.; Kulkarni, K.P.; Imran, Q.M.; Mun, B.G.; Yun, B.W. Nitric oxide regulates plant responses to drought, salinity, and heavy metal stress. Environ. Exp. Bot. 2019, 161, 120-133. [CrossRef]

110. Sohag, A.A.M.; Tahjib-Ul-Arif, M.; Afrin, S.; Khan, M.K.; Hannan, M.A.; Skalicky, M.; Mortuza, M.G.; Brestic, M.; Hossain, M.A.; Murata, Y. Insights into nitric oxide427 mediated water balance, antioxidant defence and mineral homeostasis in rice (Oryza sativa 428 L.) under chilling stress. Nitric Oxide 2020, 100, 7-16. [CrossRef] [PubMed]

111. Tanou, G.; Job, C.; Rajjou, L.; Arc, E.; Belghazi, M.; Diamantidis, G.; Molassiotis, A.; Job, D. Proteomics reveals the overlapping roles of hydrogen peroxide and nitric oxide in the acclimation of citrus plants to salinity. Plant J. Cell Mol. Biol. 2009, 60, 795-804. [CrossRef] [PubMed]

112. Zhao, G.; Zhao, Y.; Yu, X.; Kiprotich, F.; Han, H.; Guan, R.; Wang, R.; Shen, W. Nitric Oxide Is Required for Melatonin-Enhanced Tolerance against Salinity Stress in Rapeseed (Brassica napus L.) Seedlings. Int. J. Mol. Sci. 2018, 19, 1912. [CrossRef] [PubMed]

113. Fatma, M.; Masood, A.; Per, T.S.; Khan, N.A. Nitric Oxide Alleviates Salt Stress Inhibited Photosynthetic Performance by Interacting with Sulfur Assimilation in Mustard. Front. Plant Sci. 2016, 7, 521. [CrossRef] [PubMed]

114. Hasanuzzaman, M.; Oku, H.; Nahar, K.; Bhuyan, M.B.; Al Mahmud, J.; Baluska, F.; Fujita, M. Nitric oxide-induced salt stress tolerance in plants: ROS metabolism, signaling, and molecular interactions. Plant Biotechnol. Rep. 2018, 12, 77-92. [CrossRef]

115. Gohari, G.; Alavi, Z.; Esfandiari, E.; Panahirad, S.; Hajihoseinlou, S.; Fotopoulos, V. Interaction between hydrogen peroxide and sodium nitroprusside following chemical priming of Ocimumbasilicum L. against salt stress. Physiol. Plant. 2020, 168, 361-373. [CrossRef] [PubMed]

116. Hajihashemi, S.; Skalicky, M.; Brestic, M.; Pavla, V. Cross-talk between nitric oxide, hydrogen peroxide and calcium in salt-stressed. Chenopodium quinoa Willd. at seed germination stage. Plant Physiol. Biochem. 2020, 154, 657-664. [CrossRef]

117. Hossain, M.A.; Bhattacharjee, S.; Armin, S.M.; Qian, P.; Xin, W.; Li, H.Y.; Burritt, D.J.; Fujita, M.; Tran, L.S. Hydrogen peroxide priming modulates abiotic oxidative stress tolerance: Insights from ROS detoxification and scavenging. Front. Plant. Sci. 2015, 6, 420. [CrossRef] [PubMed]

118. Uddin, M.N.; Hossain, M.A.; Burritt, D.J. Salinity and drought stress: Similarities and differences in oxidative responses and cellular redox regulation. In Water Stress and Crop Plants: A Sustainable Approach; Ahmad, P., Ed.; John Wiley \& Sons: Hoboken, NJ, USA, 2016; pp. 86-101.

119. Møller, I.M.; Sweetlove, L.J. ROS signaling-specificity is required. Trends Plant. Sci. 2010, 15, 370-374. [CrossRef] [PubMed]

120. Hu, L.; Zhou, K.; Li, Y.; Chen, X.; Liu, B.; Li, C.; Gong, X.; Ma, F. Exogenous myo-inositol alleviates salinity-induced stress in Malus hupehensis Rehd. Plant Physiol. Bioch. 2018, 133, 116-126. [CrossRef] [PubMed]

121. Sun, Y.; Sun, P.; Wang, C.; Liao, J.; Ni, J.; Zhang, T.; Wang, R.; Ruan, H. Growth, physiological function, and antioxidant defense system responses of Lemna minor L. to decabromodiphenyl ether (BDE-209) induced phytotoxicity. Plant. Physiol. Bioch. 2019, 139, 113-120. [CrossRef] [PubMed]

122. Gill, S.S.; Tuteja, N. Reactive oxygen species and antioxidant machinery in abiotic stress tolerance in crop plants. Plant. Physiol. Bioch. 2010, 48, 909-930. [CrossRef]

123. Agarwal, P.K.; Shukla, P.S.; Gupta, K.; Jha, B. Bioengineering for salinity tolerance in plants: State of the art. Mol. Biotechnol. 2013, 54, 102-123. [CrossRef] [PubMed]

124. Das, K.; Roychoudhury, A. Reactive oxygen species (ROS) and response of antioxidants as ROS-scavengers during environmental stress in plants. Front. Environ. Sci. 2014, 2, 53. [CrossRef]

125. Gupta, D.K.; Palma, J.M.; Corpas, F.J. Antioxidants and Antioxidant Enzymes in Higher Plants Gupta; Springer: Cham, Switzerland, 2018.

126. Wang, H.; Chen, Y.; Hu, W.; Snider, J.L.; Zhou, Z. Short-term soil-waterlogging contributes to cotton cross tolerance to chronic elevated temperature by regulating ROS metabolism in the subtending leaf. Plant. Physiol. Bioch. 2019, 139, 333-341. [CrossRef]

127. Smékalová, V.; Doskočilová, A.; Komis, G.; Šamaj, J. Crosstalk between secondary messengers, hormones and MAPK modules during abiotic stress signalling in plants. Biotech. Adv. 2014, 32, 2-11. [CrossRef] [PubMed]

128. Suzuki, N.; Koussevitzky, S.; Mittler, R.; Miller, G. ROS and redox signalling in the response of plants to abiotic stress. Plant Cell Environ. 2012, 35, 259-270. [CrossRef] [PubMed]

129. Singhal, R.K.; Saha, D.; Skalicky, M.; Mishra, U.N.; Chauhan, J.; Behera, L.P.; Lenka, D.; Chand, S.; Kumar, V.; Dey, P.; et al. Crucial Cell Signaling Compounds Crosstalk and Integrative Multi-Omics Techniques for Salinity Stress Tolerance in Plants. Front. Plant Sci. 2021, 12, 670369. [CrossRef] [PubMed]

130. Gilliham, M.; Able, J.A.; Roy, S.J. Translating knowledge about abiotic stress tolerance to breeding programmes. Plant J. 2017, 90, 898-917. [CrossRef] [PubMed]

131. Kumar, V.; Singh, A.; Mithra, S.V.; Krishnamurthy, S.L.; Parida, S.K.; Jain, S.; Tiwari, K.K.; Kumar, P.; Rao, A.R.; Sharma, S.K.; et al. Genome-wide association mapping of salinity tolerance in rice (Oryza sativa). DNA Res. 2015, 22, 133-145. [CrossRef]

132. Pennisi, E. The CRISPR craze. Science 2013, 341, 833-836. [CrossRef]

133. Li, H.; Rasheed, A.; Hickey, L.T.; He, Z. Fast-forwarding genetic gain. Trends Plant Sci. 2018, 23, 184-186. [CrossRef]

134. Chen, S.; Jia, H.; Wang, X.; Shi, C.; Wang, X.; Ma, P.; Wang, J.; Ren, M.; Li, J. Hydrogen sulfide positively regulates abscisic acid signaling through persulfidation of SnRK2. 6 in guard cells. Mol. Plant 2020, 13, 732-744. [CrossRef] [PubMed] 
135. Ho, W.W.H.; Hill, C.B.; Doblin, M.S.; Shelden, M.C.; van de Meene, A.; Rupasinghe, T.; Bacic, A.; Roessner, U. Integrative multi-omics analyses of barley root zones under salinity stress reveal two distinctive salt tolerance mechanisms. Plant Commun. 2020, 1, 100031. [CrossRef] [PubMed]

136. Jha, U.C.; Bohra, A.; Jha, R.; Parida, S.K. Salinity stress response and 'omics' approaches for improving salinity stress tolerance in major grain legumes. Plant Cell Rep. 2019, 38, 255-277. [CrossRef]

137. Nachshon, U. Cropland Soil Salinization and Associated Hydrology: Trends, Processes and Examples. Water 2018, 10, 1030. [CrossRef]

138. Baulcombe, D.; Crute, I.; Davies, B.; Dunwell, J.; Gale, M.; Jones, J.; Pretty, J.; Sutherland, W.; Toulmin, C. Reaping the benefits: Science and the sustainable intensification of global agriculture. 2009, Report. The Royal Society, London, UK.

139. Tilman, D.; Balzer, C.; Hill, J.; Befort, B.L. Global food demand and the sustainable intensification of agriculture. Proc. Natl. Acad. Sci. USA 2011, 108, 20260-20264. [CrossRef]

140. Miransari, M.; Smith, D. Sustainable wheat (Triticum aestivum L.) production in saline fields: A review. Crit. Rev. Biotechnol. 2019, 39, 999-1014. [CrossRef] [PubMed]

141. Bannayan, M.; Eyshi Rezaei, E. Future production of rainfed wheat in Iran (Khorasan province): Climate change scenario analysis. Mitig. Adapt. Strateg. Glob. Chang. 2014, 19, 211-227. [CrossRef]

142. Gupta, B.; Huang, B. Mechanism of salinity tolerance in plants: Physiological, biochemical, and molecular characterization. Int. J. Genom. 2014, 2014, 701596. [CrossRef] [PubMed]

143. Chakraborty, K.; Sairam, R.K.; Bhaduri, D. Effects of different levels of soil salinity on yield attributes, accumulation of nitrogen, and micronutrients in Brassica spp. J. Plant Nutr. 2016, 39, 1026-1037. [CrossRef]

144. Ishitani, M.; Liu, J.; Halfter, U.; Kim, C.S.; Shi, W.; Zhu, J.K. SOS3 function in plant salt tolerance requires N-myristoylation and calcium binding. Plant Cell 2000, 12, 1667-1677. [CrossRef]

145. Shah, W.H.; Rasool, A.; Saleem, S.; Mushtaq, N.U.; Tahir, I.; Hakeem, K.R.; Rehman, R.U. Understanding the integrated pathways and mechanisms of transporters, protein kinases, and transcription factors in plants under salt stress. Int. J. Genom. 2021, 2021, 5578727. [CrossRef]

146. Quintero, F.J.; Martinez-Atienza, J.; Villalta, I.; Jiang, X.; Kim, W.Y.; Ali, Z.; Fujii, H.; Mendoza, I.; Yun, D.J.; Zhu, J.K.; et al. Activation of the plasma membrane Na/H antiporter Salt-Overly-Sensitive 1 (SOS1) by phosphorylation of an auto-inhibitory C-terminal domain. Proc. Natl. Acad. Sci. USA 2011, 108, 2611-2616. [CrossRef]

147. Martínez-Atienza, J.; Jiang, X.; Garciadeblas, B.; Mendoza, I.; Zhu, J.K.; Pardo, J.M.; Quintero, F.J. Conservation of the salt overly sensitive pathway in rice. Plant Physiol. 2007, 143, 1001-1012. [CrossRef]

148. Albrecht, V.; Ritz, O.; Linder, S.; Harter, K.; Kudla, J. The NAF domain defines a novel protein-protein interaction module conserved in $\mathrm{Ca}^{2+}$-regulated kinases. EMBO J. 2001, 20, 1051-1063. [CrossRef] [PubMed]

149. Zhou, H.; Lin, H.; Chen, S.; Becker, K.; Yang, Y.; Zhao, J.; Kudla, J.; Schumaker, K.S.; Guo, Y. Inhibition of the Arabidopsis salt overly sensitive pathway by 14-3-3 proteins. Plant Cell 2014, 26, 1166-1182. [CrossRef]

150. Chai, H.; Guo, J.; Zhong, Y.; Hsu, C.C.; Zou, C.; Wang, P.; Zhu, J.K.; Shi, H. The plasma-membrane polyamine transporter PUT3 is regulated by the $\mathrm{Na}^{+} / \mathrm{H}^{+}$antiporter SOS1 and protein kinase SOS2. New Phytol. 2020, 226, 785-797. [CrossRef] [PubMed]

151. Lin, H.; Yang, Y.; Quan, R.; Mendoza, I.; Wu, Y.; Du, W.; Zhao, S.; Schumaker, K.S.; Pardo, J.M.; Guo, Y. Phosphorylation of SOS3-like calcium binding protein 8 by SOS2 protein kinase stabilizes their protein complex and regulates salt tolerance in Arabidopsis. Plant Cell 2009, 21, 1607-1619. [CrossRef]

152. Assaha, D.V.; Ueda, A.; Saneoka, H.; Al-Yahyai, R.; Yaish, M.W. The role of $\mathrm{Na}^{+}$and $\mathrm{K}^{+}$transporters in salt stress adaptation in glycophytes. Front. Physiol. 2017, 8, 509. [CrossRef] [PubMed]

153. Tsuchisaka, A.; Yu, G.; Jin, H.; Alonso, J.M.; Ecker, J.R.; Zhang, X.; Gao, S.; Theologis, A. A combinatorial interplay among the 1-aminocyclopropane-1-carboxylate isoforms regulates ethylene biosynthesis in Arabidopsis thaliana. Genetics 2009, 183, 979-1003. [CrossRef] [PubMed]

154. Arraes, F.B.M.; Beneventi, M.A.; de Sa, M.E.L.; Paixao, J.F.R.; Albuquerque, E.V.S.; Marin, S.R.R.; Purgatto, E.; Nepomuceno, A.L.; Grossi-de-Sa, M.F. Implications of ethylene biosynthesis and signaling in soybean drought stress tolerance. BMC Plant Biol. 2015, 15, 1-20. [CrossRef] [PubMed]

155. Lorenzo, O.; Piqueras, R.; Sánchez-Serrano, J.J.; Solano, R. Ethylene Response Factor1 integrates signals from ethylene and jasmonate pathways in plant defense. Plant Cell 2003, 15, 165-178. [CrossRef] [PubMed]

156. Guzman, P.; Ecker, J.R. Exploiting the triple response of Arabidopsis to identify ethylene-related mutants. Plant Cell 1990, 2, 513-523. [CrossRef]

157. Daszkowska-Golec, A.; Szarejko, I. Open or close the gate-stomata action under the control of phytohormones in drought stress conditions. Front. Plant Sci. 2013, 4, 138. [CrossRef]

158. Tanaka, Y.; Sano, T.; Tamaoki, M.; Nakajima, N.; Kondo, N.; Hasezawa, S. Ethylene inhibits abscisic acid-induced stomatal closure in Arabidopsis. Plant Physiol. 2005, 138, 2337-2343. [CrossRef]

159. Kim, T.H.; Böhmer, M.; Hu, H.; Nishimura, N.; Schroeder, J.I. Guard cell signal transduction network: Advances in understanding abscisic acid, $\mathrm{CO}_{2}$, and $\mathrm{Ca}^{2+}$ signaling. Annu. Rev. Plant Biol. 2010, 61, 561-591. [CrossRef]

160. Wang, K.L.C.; Li, H.; Ecker, J.R. Ethylene biosynthesis and signaling networks. Plant Cell 2002, 14, S131-S151. [CrossRef] [PubMed] 
161. Thomann, A.; Lechner, E.; Hansen, M.; Dumbliauskas, E.; Parmentier, Y.; Kieber, J.; Scheres, B.; Genschik, P. Arabidopsis CULLIN3 genes regulate primary root growth and patterning by ethylene-dependent and-independent mechanisms. PLoS Genet. 2009, 5, e1000328. [CrossRef] [PubMed]

162. Argueso, C.T.; Hansen, M.; Kieber, J.J. Regulation of ethylene biosynthesis. J. Plant Growth Regul. 2007, 26, 92-105. [CrossRef]

163. Dong, H.; Zhen, Z.; Peng, J.; Chang, L.; Gong, Q.; Wang, N.N. Loss of ACS7 confers abiotic stress tolerance by modulating ABA sensitivity and accumulation in Arabidopsis. J. Exp. Bot. 2011, 62, 4875-4887. [CrossRef] [PubMed]

164. Song, Q.; Ando, A.; Xu, D.; Fang, L.; Zhang, T.; Huq, E.; Qiao, H.; Deng, X.W.; Chen, Z.J. Diurnal down-regulation of ethylene biosynthesis mediates biomass heterosis. Proc. Natl. Acad. Sci. USA 2018, 115, 5606-5611. [CrossRef] [PubMed]

165. Yamagami, T.; Tsuchisaka, A.; Yamada, K.; Haddon, W.F.; Harden, L.A.; Theologis, A. Biochemical diversity among the 1-aminocyclopropane-1-carboxylate synthase isozymes encoded by the Arabidopsis gene family. J. Biol. Chem. 2003, 278, 49102-49112. [CrossRef] [PubMed]

166. Lee, H.Y.; Yoon, G.M. Regulation of ethylene biosynthesis by phytohormones in etiolated rice (Oryza sativa L.) seedlings. Mol. Cells 2018, 41, 311. [CrossRef]

167. Yoon, G.M. New insights into the protein turnover regulation in ethylene biosynthesis. Mol. Cells 2015, 38, 597. [CrossRef]

168. Pegoraro, C.; Farias, D.D.R.; Mertz, L.M.; Santos, R.S.D.; Maia, L.C.D.; Rombaldi, C.V.; Oliveira, A.C.D. Ethylene response factors gene regulation and expression profiles under different stresses in rice. Theor. Exp. Plant Physiol. 2013, 25, 261-274. [CrossRef]

169. Nomoto, Y.; Kubozono, S.; Yamashino, T.; Nakamichi, N.; Mizuno, T. Circadian clock-and PIF4-controlled plant growth: A coincidence mechanism directly integrates a hormone signaling network into the photoperiodic control of plant architectures in Arabidopsis thaliana. Plant Cell Physiol. 2012, 53, 1950-1964. [CrossRef]

170. Shin, K.; Lee, S.; Song, W.Y.; Lee, R.A.; Lee, I.; Ha, K.; Koo, J.C.; Park, S.K.; Nam, H.G.; Lee, Y.; et al. Genetic identification of ACCRESISTANT2 reveals involvement of LYSINE HISTIDINE TRANSPORTER1 in the uptake of 1-aminocyclopropane-1-carboxylic acid in Arabidopsis thaliana. Plant Cell Physiol. 2015, 56, 572-582. [CrossRef]

171. Dubois, M.; Van den Broeck, L.; Inzé, D. The pivotal role of ethylene in plant growth. Trends Plant Sci. 2018, 23, 311-323. [CrossRef] [PubMed]

172. Wilson, R.L.; Lacey, R.F.; Binder, B.M. Ethylene receptors-biochemical events. In Ethylene in Plants; Wen, C.K., Ed.; Springer: Dordrecht, The Netherlands, 2015; pp. 45-59. [CrossRef]

173. Ju, C.; Chang, C. Mechanistic insights in ethylene perception and signal transduction. Plant Physiol. 2015, 169, 85-95. [CrossRef] [PubMed]

174. Cho, C.H.; Sung, H.K.; Kim, K.T.; Cheon, H.G.; Oh, G.T.; Hong, H.J.; Yoo, O.J.; Koh, G.Y. COMP-angiopoietin-1 promotes wound healing through enhanced angiogenesis, lymphangiogenesis, and blood flow in a diabetic mouse model. Proc. Natl. Acad. Sci. USA 2006, 103, 4946-4951. [CrossRef] [PubMed]

175. Shi, J.; Drummond, B.J.; Wang, H.; Archibald, R.L.; Habben, J.E. Maize and Arabidopsis ARGOS proteins interact with ethylene receptor signaling complex, supporting a regulatory role for ARGOS in ethylene signal transduction. Plant Physiol. 2016, 171, 2783-2797. [CrossRef]

176. Lacey, R.F.; Binder, B.M. How plants sense ethylene gas-The ethylene receptors. J. Inorg. Biochem. 2014, 133, 58-62. [CrossRef]

177. Shakeel, S.N.; Gao, Z.; Amir, M.; Chen, Y.F.; Rai, M.I.; Haq, N.U.; Schaller, G.E. Ethylene regulates levels of ethylene receptor/CTR1 signaling complexes in Arabidopsis thaliana. J. Biol. Chem. 2015, 290, 12415-12424. [CrossRef] [PubMed]

178. Qiao, H.; Chang, K.N.; Yazaki, J.; Ecker, J.R. Interplay between ethylene, ETP1/ETP2 F-box proteins, and degradation of EIN2 triggers ethylene responses in Arabidopsis. Genes Dev. 2009, 23, 512-521. [CrossRef] [PubMed]

179. Wang, Q.; Dodd, I.C.; Belimov, A.A.; Jiang, F. Rhizosphere bacteria containing 1-aminocyclopropane-1-carboxylate deaminase increase growth and photosynthesis of pea plants under salt stress by limiting $\mathrm{Na}^{+}$accumulation. Funct. Plant Biol. 2016, 43, 161-172. [CrossRef] [PubMed]

180. Jiang, C.; Belfield, E.J.; Cao, Y.; Smith, J.A.C.; Harberd, N.P. An Arabidopsis soil-salinity-tolerance mutation confers ethylenemediated enhancement of sodium/potassium homeostasis. Plant Cell 2013, 25, 3535-3552. [CrossRef] [PubMed]

181. Tao, J.J.; Chen, H.W.; Ma, B.; Zhang, W.K.; Chen, S.Y.; Zhang, J.S. The role of ethylene in plants under salinity stress. Front. Plant Sci. 2015, 6, 1059. [CrossRef]

182. Nakano, T.; Suzuki, K.; Ohtsuki, N.; Tsujimoto, Y.; Fujimura, T.; Shinshi, H. Identification of genes of the plant-specific transcription-factor families cooperatively regulated by ethylene and jasmonate in Arabidopsis thaliana. J. Plant Res. 2006, 119, 407-413. [CrossRef] [PubMed]

183. Cao, Y.R.; Chen, S.Y.; Zhang, J.S. Ethylene signaling regulates salt stress response: An overview. Plant Signal. Behav. 2008, 3, 761-763. [CrossRef] [PubMed]

184. Wilson, R.L.; Kim, H.; Bakshi, A.; Binder, B.M. The ethylene receptors Ethylene resonse1 and Ethylene response2 have contrasting roles in seed germination of Arabidopsis during salt stress. Plant Physiol. 2014, 165, 1353-1366. [CrossRef]

185. Yu, Y.; Wang, J.; Shi, H.; Gu, J.; Dong, J.; Deng, X.W.; Huang, R. Salt stress and ethylene antagonistically regulate nucleocytoplasmic partitioning of COP1 to control seed germination. Plant Physiol. 2016, 170, 2340-2350. [CrossRef]

186. Chervin, C.; Tira-umphon, A.; Terrier, N.; Zouine, M.; Severac, D.; Roustan, J.P. Stimulation of the grape berry expansion by ethylene and effects on related gene transcripts, over the ripening phase. Physiol. Plant. 2008, 134, 534-546. [CrossRef] [PubMed]

187. Dubois, M.; Claeys, H.; Van den Broeck, L.; Inzé, D. Time of day determines Arabidopsis transcriptome and growth dynamics under mild drought. Plant Cell Environ. 2017, 40, 180-189. [CrossRef] [PubMed] 
188. Meng, X.; Xu, J.; He, Y.; Yang, K.Y.; Mordorski, B.; Liu, Y.; Zhang, S. Phosphorylation of an ERF transcription factor by Arabidopsis MPK3/MPK6 regulates plant defense gene induction and fungal resistance. Plant Cell 2013, 25, 1126-1142. [CrossRef] [PubMed]

189. Fedorov, D.N.; Ekimova, G.A.; Doronina, N.V.; Trotsenko, Y.A. 1-Aminocyclopropane-1-carboxylate (ACC) deaminases from Methylobacteriumradiotolerans and Methylobacteriumnodulans with higher specificity for ACC. FEMS Microbiol. Lett. 2013, 343, 70-76. [CrossRef]

190. Ali, S.; Glick, B.R. Biochemistry and molecular biology of the enzyme ACC deaminase. In Microbes: The Foundation Stone of the Biosphere; Hurst, C.J., Ed.; Springer: Cham, Switzerland, 2021; pp. 365-390. [CrossRef]

191. Nascimento, F.X.; Rossi, M.J.; Soares, C.R.; McConkey, B.J.; Glick, B.R. New insights into 1-aminocyclopropane-1-carboxylate (ACC) deaminase phylogeny, evolution and ecological significance. PLoS ONE 2014, 9, e99168. [CrossRef] [PubMed]

192. Karthikeyan, S.; Zhou, Q.; Zhao, Z.; Kao, C.L.; Tao, Z.; Robinson, H.; Liu, H.W.; Zhang, H. Structural analysis of Pseudomonas 1-aminocyclopropane-1-carboxylate deaminase complexes: Insight into the mechanism of a unique pyridoxal-5'-phosphate dependent cyclopropane ring-opening reaction. Biochemistry 2004, 43, 13328-13339. [CrossRef] [PubMed]

193. Minami, R.; Uchiyama, K.; Murakami, T.; Kawai, J.; Mikami, K.; Yamada, T.; Yokoi, D.; Ito, H.; Matsui, H.; Honma, M. Properties, sequence, and synthesis in Escherichia coli of 1-aminocyclopropane-1-carboxylate deaminase from Hansenulasaturnus. J. Biochem. 1998, 123, 1112-1118. [CrossRef]

194. Ose, T.; Fujino, A.; Yao, M.; Watanabe, N.; Honma, M.; Tanaka, I. Reaction intermediate structures of 1-aminocyclopropane-1carboxylate deaminase: Insight into PLP-dependent cyclopropane ring-opening reaction. J. Biol. Chem. 2003, 278, 41069-41076. [CrossRef]

195. Hontzeas, N.; Zoidakis, J.; Glick, B.R.; Abu-Omar, M.M. Expression and characterization of 1-aminocyclopropane-1-carboxylate deaminase from the rhizobacterium Pseudomonas putida UW4: A key enzyme in bacterial plant growth promotion. Biochim. Biophys. Acta Proteins Proteom. 2004, 1703, 11-19. [CrossRef]

196. Glick, B.R. Bacteria with ACC deaminase can promote plant growth and help to feed the world. Microbiol. Res. 2014, 169, 30-39. [CrossRef] [PubMed]

197. Singh, R.P.; Shelke, G.M.; Kumar, A.; Jha, P.N. Biochemistry and genetics of ACC deaminase: A weapon to "stress ethylene" produced in plants. Front. Microbiol. 2015, 6, 937. [CrossRef] [PubMed]

198. Danish, S.; Zafar-ul-Hye, M. Co-application of ACC-deaminase producing PGPR and timber-waste biochar improves pigments formation, growth and yield of wheat under drought stress. Sci. Rep. 2019, 9, 1-13. [CrossRef] [PubMed]

199. Gupta, S.; Pandey, S. ACC deaminase producing bacteria with multifarious plant growth promoting traits alleviates salinity stress in French bean (Phaseolus vulgaris) plants. Front. Microbiol. 2019, 10, 1506. [CrossRef] [PubMed]

200. Hontzeas, N.; Hontzeas, C.E.; Glick, B.R. Reaction mechanisms of the bacterial enzyme 1-aminocyclopropane-1-carboxylate deaminase. Biotechnol. Adv. 2006, 24, 420-426. [CrossRef]

201. Grichko, V.P.; Glick, B.R. Identification of DNA sequences that regulate the expression of the Enterobacter cloacae UW4 1aminocyclopropane-1-carboxylic acid deaminase gene. Can. J. Microbiol. 2000, 46, 1159-1165. [CrossRef] [PubMed]

202. Li, J.; Glick, B.R. Transcriptional regulation of the Enterobacter cloacae UW4 1-aminocyclopropane-1-carboxylate (ACC) deaminase gene (acdS). Can. J. Microbiol. 2001, 47, 359-367. [CrossRef] [PubMed]

203. van Loon, L.C.; Glick, B.R. Increased plant fitness by rhizobacteria. In Molecular Ecotoxicology of Plants; Sanderman, H., Ed.; Springer: Heidelberg, Germany, 2004; pp. 177-205. [CrossRef]

204. Cheng, Z.; Duncker, B.P.; McConkey, B.J.; Glick, B.R. Transcriptional regulation of ACC deaminase gene expression in Pseudomonasputida UW4. Can. J. Microbiol. 2008, 54, 128-136. [CrossRef]

205. Prigent-Combaret, C.; Blaha, D.; Pothier, J.F.; Vial, L.; Poirier, M.A.; Wisniewski-Dyé, F.; Moënne-Loccoz, Y. Physical organization and phylogenetic analysis of $a c d R$ as leucine-responsive regulator of the 1-aminocyclopropane-1-carboxylate deaminase gene acdS in phytobeneficial Azospirillumlipoferum 4B and other Proteobacteria. FEMS Microbiol. Ecol. 2008, 65, 202-219. [CrossRef]

206. Nukui, N.; Minamisawa, K.; Ayabe, S.I.; Aoki, T. Expression of the 1-aminocyclopropane-1-carboxylic acid deaminase gene requires symbiotic nitrogen-fixing regulator gene nifA2 in Mesorhizobium loti MAFF303099. Appl. Environ. Microbiol. 2006, 72, 4964-4969. [CrossRef] [PubMed]

207. Saleh, S.S.; Glick, B.R. Involvement of gacS and rpoS in enhancement of the plant growth-promoting capabilities of Enterobacter cloacae CAL2 and UW4. Can. J. Microbiol. 2001, 47, 698-705. [CrossRef] [PubMed]

208. Hengge-Aronis, R. Signal transduction and regulatory mechanisms involved in control of the $\sigma \mathrm{S}$ (RpoS) subunit of RNA polymerase. Microbiol. Mol. Biol. Rev. 2002, 66, 373-395. [CrossRef]

209. Osiriphun, Y.; Wongtrakoongate, P.; Sanongkiet, S.; Suriyaphol, P.; Thongboonkerd, V.; Tungpradabkul, S. Identification and characterization of RpoS regulon and RpoS-dependent promoters in Burkholderiapseudomallei. J. Proteome Res. 2009, 8, 3118-3131. [CrossRef] [PubMed]

210. Shah, S.; Li, J.; Moffatt, B.A.; Glick, B.R. Isolation and characterization of ACC deaminase genes from two different plant growth-promoting rhizobacteria. Can. J. Microbiol. 1998, 44, 833-843. [CrossRef]

211. Grichko, V.P.; Glick, B.R. Amelioration of flooding stress by ACC deaminase-containingplant growth-promoting bacteria. Plant Physiol. Biochem. 2001, 39, 11-17. [CrossRef]

212. Boyer, J.S. Plant productivity and environment. Science 1982, 218, 443-448. [CrossRef] [PubMed]

213. Bray, E.A.; Bailey-Serres, J.; Weretilnyk, E. Responses to abiotic stresses. In Biochemistry and Molecular Biology of Plants; Gruissem, W., Buchannan, B., Jones, R., Eds.; American Society of Plant Physiologists: Rockville, MD, USA, 2000; pp. $1158-1249$. 
214. Goswami, M.; Suresh, D.E.K.A. Plant growth-promoting rhizobacteria-alleviators of abiotic stresses in soil: A review. Pedosphere 2020, 30, 40-61. [CrossRef]

215. Gray, E.J.; Smith, D.L. Intracellular and extracellular PGPR: Commonalities and distinctions in the plant-bacterium signaling processes. Soil Biol. Biochem. 2005, 37, 395-412. [CrossRef]

216. Miransari, M.; Smith, D.L. Overcoming the stressful effects of salinity and acidity on soybean nodulation and yields using signal molecule genistein under field conditions. J Plant Nutr. 2007, 30, 1967-1992. [CrossRef]

217. Miransari, M.; Bahrami, H.A.; Rejali, F.; Malakouti, M.J. Using arbuscular mycorrhiza to alleviate the stress of soil compaction on wheat (Triticum aestivum L.) growth. Soil Biol. Biochem. 2008, 40, 1197-1206. [CrossRef]

218. Miransari, M.; Smith, D.L. Alleviating salt stress on soybean (Glycine max (L.) Merr.)-Bradyrhizobium japonicum symbiosis, using signal molecule genistein. Eur. J. Soil Biol. 2009, 45, 146-152. [CrossRef]

219. Daei, G.; Ardekani, M.R.; Rejali, F.; Teimuri, S.; Miransari, M. Alleviation of salinity stress on wheat yield, yield components, and nutrient uptake using arbuscular mycorrhizal fungi under field conditions. J. Plant Physiol. 2009, 166, 617-625. [CrossRef] [PubMed]

220. Arzanesh, M.H.; Alikhani, H.A.; Khavazi, K.; Rahimian, H.A.; Miransari, M. Wheat (Triticum aestivum L.) growth enhancement by Azospirillum sp. under drought stress. World J. Microbiol. Biotech. 2011, 27, 197-205. [CrossRef]

221. Złoch, M.; Thiem, D.; Gadzała-Kopciuch, R.; Hrynkiewicz, K. Synthesis of siderophores by plant-associated metallotolerant bacteria under exposure to $\mathrm{Cd}^{2+}$. Chemosphere 2016, 156, 312-325. [CrossRef] [PubMed]

222. Sunita, K.; Mishra, I.; Mishra, J.; Prakash, J.; Arora, N.K. Secondary metabolites from halotolerant plant growth promoting rhizobacteria for ameliorating salinity stress in plants. Front. Microbiol. 2020, 11, 2619. [CrossRef] [PubMed]

223. Ilangumaran, G.; Smith, D.L. Plant growth promoting rhizobacteria in amelioration of salinity stress: A systems biology perspective. Front. Plant Sci. 2017, 8, 1768. [CrossRef] [PubMed]

224. Vardharajula, S.; Ali, S.Z.; Grover, M.; Reddy, G.; Bandi, V. Drought-tolerant plant growth promoting Bacillus spp.: Effect on growth, osmolytes, and antioxidant status of maize under drought stress. J. Plant Interact. 2011, 6, 1-14. [CrossRef]

225. Tanaka, K.; Cho, S.H.; Lee, H.; Pham, A.Q.; Batek, J.M.; Cui, S.; Qiu, J.; Khan, S.M.; Joshi, T.; Zhang, Z.J.; et al. Effect of lipo-chitooligosaccharide on early growth of $\mathrm{C}_{4}$ grass seedlings. J. Exp. Bot. 2015, 66, 5727-5738. [CrossRef] [PubMed]

226. Sharma, S.; Kulkarni, J.; Jha, B. Halotolerant rhizobacteria promote growth and enhance salinity tolerance in peanut. Front. Microbiol. 2016, 7, 1600. [CrossRef] [PubMed]

227. Abbas, R.; Rasul, S.; Aslam, K.; Baber, M.; Shahid, M.; Mubeen, F.; Naqqash, T. Halotolerant PGPR: A hope for cultivation of saline soils. J. King Saud Univ. Sci. 2019, 31, 1195-1201. [CrossRef]

228. Habib, S.H.; Kausar, H.; Saud, H.M. Plant growth-promoting rhizobacteria enhance salinity stress tolerance in Okra through ROS-scavenging enzymes. Biomed Res. Int. 2016, 2016, 6284547. [CrossRef] [PubMed]

229. Glick, B.R.; Todorovic, B.; Czarny, J.; Cheng, Z.; Duan, J.; McConkey, B. Promotion of plant growth by bacterial ACC deaminase. Crit. Rev. Plant Sci. 2007, 26, 227-242. [CrossRef]

230. Penrose, D.M.; Glick, B.R. Methods for isolating and characterizing ACC deaminase-containing plant growth-promoting rhizobacteria. Physiol. Plant. 2003, 118, 10-15. [CrossRef]

231. Honma, M.; Shimomura, T. Metabolism of 1-aminocyclopropane-1-carboxylic acid. Agric. Biol. Chem. 1978, $42,1825-1831$. [CrossRef]

232. Yildirim, E.R.T.A.N.; Turan, M.E.T.I.N.; Donmez, M.F. Mitigation of salt stress in radish (Raphanus sativus L.) by plant growth promoting rhizobacteria. Roum. Biotechnol. Lett. 2008, 13, 3933-3943.

233. Nadeem, S.M.; Zahir, Z.A.; Naveed, M.; Arshad, M. Rhizobacteria containing ACC-deaminase confer salt tolerance in maize grown on salt-affected fields. Can. J. Microbiol. 2009, 55, 1302-1309. [CrossRef]

234. Yao, L.; Wu, Z.; Zheng, Y.; Kaleem, I.; Li, C. Growth promotion and protection against salt stress by Pseudomonas putida Rs-198 on cotton. Eur. J. Soil Biol. 2010, 46, 49-54. [CrossRef]

235. Abd El-Azeem, S.A.; Elwan, M.W.; Sung, J.K.; Ok, Y.S. Alleviation of salt stress in eggplant (Solanum melongena L.) by plantgrowth-promoting rhizobacteria. Commun. Soil Sci. Plant Anal. 2012, 43, 1303-1315. [CrossRef]

236. Mohamed, H.I.; Gomaa, E.Z. Effect of plant growth promoting Bacillus subtilis and Pseudomonas fluorescens on growth and pigment composition of radish plants (Raphanus sativus) under $\mathrm{NaCl}$ stress. Photosynthetica 2012, 50, 263-272. [CrossRef]

237. Siddikee, M.A.; Chauhan, P.S.; Sa, T. Regulation of ethylene biosynthesis under salt stress in red pepper (Capsicum annuum L.) by 1-aminocyclopropane-1-carboxylic acid (ACC) deaminase-producing halotolerant bacteria. J. Plant Growth Regul. 2012, 31 , 265-272. [CrossRef]

238. Kang, S.M.; Khan, A.L.; Waqas, M.; You, Y.H.; Kim, J.H.; Kim, J.G.; Hamayun, M.; Lee, I.J. Plant growth-promoting rhizobacteria reduce adverse effects of salinity and osmotic stress by regulating phytohormones and antioxidants in Cucumis sativus. J. Plant Interact. 2014, 9, 673-682. [CrossRef]

239. Yan, J.; Smith, M.D.; Glick, B.R.; Liang, Y. Effects of ACC deaminase containing rhizobacteria on plant growth and expression of Toc GTPases in tomato (Solanum lycopersicum) under salt stress. Botany 2014, 92, 775-781. [CrossRef]

240. Chen, L.; Liu, Y.; Wu, G.; VeronicanNjeri, K.; Shen, Q.; Zhang, N.; Zhang, R. Induced maize salt tolerance by rhizosphere inoculation of Bacillus amyloliquefaciens SQR9. Physiol. Plant. 2016, 158, 34-44. [CrossRef] [PubMed]

241. Lee, G.W.; Lee, K.J.; Chae, J.C. Herbaspirillum sp. strain GW103 alleviates salt stress in Brassica rapa L. ssp. pekinensis. Protoplasma 2016, 253, 655-661. [CrossRef] [PubMed] 
242. Niu, S.Q.; Li, H.R.; Paré, P.W.; Aziz, M.; Wang, S.M.; Shi, H.; Li, J.; Han, Q.Q.; Guo, S.Q.; Li, J.; et al. Induced growth promotion and higher salt tolerance in the halophyte grass Puccinelliatenuiflora by beneficial rhizobacteria. Plant Soil 2016, 407, 217-230. [CrossRef]

243. Panwar, M.; Tewari, R.; Gulati, A.; Nayyar, H. Indigenous salt-tolerant rhizobacterium Pantoeadispersa (PSB3) reduces sodium uptake and mitigates the effects of salt stress on growth and yield of chickpea. Acta Physiol. Plant. 2016, 38, 1-12. [CrossRef]

244. Zerrouk, I.Z.; Benchabane, M.; Khelifi, L.; Yokawa, K.; Ludwig-Müller, J.; Baluska, F. A Pseudomonas strain isolated from date-palm rhizospheres improves root growth and promotes root formation in maize exposed to salt and aluminum stress. J. Plant Physiol. 2016, 191, 111-119. [CrossRef]

245. Hahm, M.S.; Son, J.S.; Hwang, Y.J.; Kwon, D.K.; Ghim, S.Y. Alleviation of salt stress in pepper (Capsicum annum L.) plants by plant growth-promoting rhizobacteria. J. Microbiol. Biotechnol. 2017, 27, 1790-1797. [CrossRef] [PubMed]

246. El-Esawi, M.A.; Alaraidh, I.A.; Alsahli, A.A.; Alzahrani, S.M.; Ali, H.M.; Alayafi, A.A.; Ahmad, M. Serratia liquefaciens KM4 improves salt stress tolerance in maize by regulating redox potential, ion homeostasis, leaf gas exchange and stress-related gene expression. Int. J. Mol. Sci. 2018, 19, 3310. [CrossRef] [PubMed]

247. Sapre, S.; Gontia-Mishra, I.; Tiwari, S. Klebsiella sp. confers enhanced tolerance to salinity and plant growth promotion in oat seedlings (Avena sativa). Microbiol. Res. 2018, 206, 25-32. [CrossRef]

248. Sarkar, A.; Ghosh, P.K.; Pramanik, K.; Mitra, S.; Soren, T.; Pandey, S.; Mondal, M.H.; Maiti, T.K. A halotolerant Enterobacter sp. displaying ACC deaminase activity promotes rice seedling growth under salt stress. Res. Microbiol. 2018, 169, 20-32. [CrossRef]

249. Sarkar, A.; Pramanik, K.; Mitra, S.; Soren, T.; Maiti, T.K. Enhancement of growth and salt tolerance of rice seedlings by ACC deaminase-producing Burkholderia sp. MTCC 12259. J. Plant Physiol. 2018, 231, 434-442. [CrossRef]

250. He, Y.; Wu, Z.; Wang, W.; Ye, B.C.; Zhang, F.; Liu, X. Different responses of Capsicum annuum L. root and shoot to salt stress with Pseudomonas putida Rs-198 inoculation. J. Plant Growth Regul. 2019, 38, 799-811. [CrossRef]

251. Kang, S.M.; Shahzad, R.; Bilal, S.; Khan, A.L.; Park, Y.G.; Lee, K.E.; Asaf, S.; Khan, M.A.; Lee, I.J. Indole-3-acetic-acid and ACC deaminase producing Leclerciaadecarboxylata MO1 improves Solanum lycopersicum L. growth and salinity stress tolerance by endogenous secondary metabolites regulation. BMC Microbiol. 2019, 19, 1-14. [CrossRef] [PubMed]

252. Zerrouk, I.Z.; Rahmoune, B.; Khelifi, L.; Mounir, K.; Baluska, F.; Ludwig-Müller, J. Algerian Sahara PGPR confers maize root tolerance to salt and aluminum toxicity via ACC deaminase and IAA. Acta Physiol. Plant. 2019, 41, 91. [CrossRef]

253. Latef, A.A.H.A.; Alhmad, M.F.A.; Kordrostami, M.; Abo-Baker, A.B.A.E.; Zakir, A. Inoculation with Azospirillumlipoferum or Azotobacter chroococcum reinforces maize growth by improving physiological activities under saline conditions. J. Plant Growth Regul. 2020, 39, 1293-1306. [CrossRef]

254. Alexander, A.; Singh, V.K.; Mishra, A. Halotolerant PGPR Stenotrophomonasmaltophilia BJ01 induces salt tolerance by modulating physiology and biochemical activities of Arachis hypogaea. Front. Microbiol. 2020, 11, 2530. [CrossRef] [PubMed]

255. Li, X.; Sun, P.; Zhang, Y.; Jin, C.; Guan, C. A novel PGPR strain Kocuriarhizophila Y1 enhances salt stress tolerance in maize by regulating phytohormone levels, nutrient acquisition, redox potential, ion homeostasis, photosynthetic capacity and stressresponsive genes expression. Environ. Exp. Bot. 2020, 174, 104023. [CrossRef]

256. Mahadik, S.; Kumudini, B.S. Enhancement of salinity stress tolerance and plant growth in finger millet using fluorescent pseudomonads. Rhizosphere 2020, 15, 100226. [CrossRef]

257. Misra, S.; Chauhan, P.S. ACC deaminase-producing rhizosphere competent Bacillus spp. mitigate salt stress and promote Zea mays growth by modulating ethylene metabolism. 3 Biotech 2020, 10, 1-14. [CrossRef] [PubMed]

258. Vaishnav, A.; Singh, J.; Singh, P.; Rajput, R.S.; Singh, H.B.; Sarma, B.K. Sphingobacterium sp. BHU-AV3 induces salt tolerance in tomato by enhancing antioxidant activities and energy metabolism. Front. Microbiol. 2020, 11, 443. [CrossRef] [PubMed] 